\title{
Troublesome Tidings? Investors' Response to a Wells Notice
}

\author{
Paul A. Griffin ${ }^{1} \&$ Estelle Y. Sun ${ }^{2}$ \\ ${ }^{1}$ Graduate School of Management, University of California, Davis, CA 95616 USA \\ ${ }^{2}$ Questrom School of Business, Boston University, Boston, MA 02215 USA \\ Correspondence: Paul A. Griffin, Graduate School of Management, University of California, Davis, CA 95616 USA
}

Received: December 8, 2015

Accepted: December 28, 2015

Online Published: January 12, 2016

doi:10.5430/afr.v5n1p99

URL: http://dx.doi.org/10.5430/afr.v5n1p99

\begin{abstract}
While the SEC has issued Wells notices for many decades, scant evidence has amassed about how such notices affect stock prices. This study fills that void and finds significantly negative excess stock returns over the three days around first-time Wells disclosures in company $8-\mathrm{K}$ filings. For first-time 8 -K disclosures that involve timely subsequent litigation, stock prices fall sharply, resulting in a cumulative average three-day excess stock return of -4.5 percent. In addition, we observe no significant price response for firms that wait to disclose their first-time Wells disclosure in a $10-\mathrm{K}$ or $10-\mathrm{Q}$. This raises the possibility that some managers choose the potentially less ethical option of disclosing on a delayed basis to avoid or mute the initial 8-K effect. Our results also imply that prior research on SEC or shareholder litigation or restatement events may have understated investors' response to those events by not considering the earlier Wells notice response.
\end{abstract}

Keywords: Wells notice, Securities and exchange commission, Investors' response, Disclosure regulation, Event study

JEL Classification: G14, K22, M41.

Data availability: All data are from public sources.

\section{Introduction}

\subsection{Background}

A Wells notice issued by the SEC staff informs a registrant company or its officers of findings that may help a staff recommendation to the Commission that it authorizes charges against the company or its officers for a violation of securities law. (Note 1) Investors often treat disclosure of a Wells notice with much concern because it may prompt shareholders to initiate a securities class action claim for damages or could be the first tiding of a possible SEC fraud investigation. Securities fraud can be very costly. According to The Association of Certified Fraud Examiners' 2010 Report to the Nations on Occupational Fraud and Abuse report, financial statement fraud costs approximately five percent of firms' annual revenue on average (Robinson, Robertson, \& Curtis, 2012). Events that signal a possible litigation action may, therefore, deserve separate disclosure by firms and warrant detailed analyses by researchers.

While SEC has issued Wells notice for many decades, there is scant evidence about how such notice might affect stock prices. One reason is that current SEC rules do not oblige firms to disclose the receipt of a Wells notice, primarily because such notice does not meet the Regulation S-K, Item 103, rule for disclosure of a material pending legal proceeding but not an inquiry such as a Wells notice. It is, therefore, up to firm managers to decide whether and when to disclose. On the one hand, a manager might determine that a Wells disclosure conveys little new price-sensitive information to investors and, thus, disclose it promptly because the stock price may already impound considerable public information about litigation risk. (Note 2) On the other hand, if a Wells disclosure associates with a significant stock price penalty, then managers who care about short-term stock prices may strategically delay disclosure or choose not to disclose. Still, the initial receipt of a Wells notice by a non-discloser could be revealed to investors in a subsequent filing or other legal proceeding. However, by that time later events might foreshadow the news content of the notice and neutralize the negative stock impact. The act of delayed or non-disclosure could also be considered unethical managerial behavior, prompting shareholders to question company performance (Donker, Poff, \& Zahir, 2008). 


\subsection{Objective}

This paper examines investors' response to the disclosure of receipt of a Wells notice. First, we test whether investors respond negatively around the firm's first disclosure of a Wells notice. Second, we test whether the negative response varies with the severity of a possible securities violation, that is, the litigation risk that investors would assess based on contemporaneous public information versus the additional litigation risk that investors might discern from a Wells notice disclosure. Our topic is important because managers should understand the market effects of a Wells disclosure. Investors can also better understand managers' disclosure incentives by observing the timing of managers' disclosure.

\subsection{Summary of Results and Contribution}

Based on a sample of 603 Wells notices disclosed in SEC filings over 2000 to 2009, including 119 first-time disclosures, we document the following. First, we find that investors interpret a Wells disclosure as a significant adverse event, particularly first-time 8-K disclosures and when SEC or shareholder litigation follows within 12 months of the 8-K filing (timely litigation). For first-time 8-K Wells disclosers with timely litigation, we document a cumulative mean excess return of -4.5 percent in the three days around the disclosure. We do not find a significantly negative response for first-time $10-\mathrm{K} / 10-\mathrm{Q}$ disclosers. This raises the possibility that some firms receiving a Wells notice might choose to disclose on a delayed basis in a 10-K or 10-Q filing (39 of the 119 first-time disclosures in our sample) to avoid the 8-K effect.

Second, we document a significant relation between investors' response to first-time 8-K disclosures and information about the likelihood of litigation and/or the severity or cost of that litigation (hereafter, litigation risk). We proxy for litigation risk in two ways. When we proxy for litigation risk based on foreknowledge of SEC or shareholder litigation, we find a significantly negative relation between litigation risk and market-adjusted excess return, after controlling for other factors such as size, earnings, and growth. On the other hand, when we proxy for litigation risk based on a prediction model that uses public information known to investors at the time of the disclosure (ex-ante litigation risk), we find no such negative relation. This result comports with the view that investors' response to a first-time Wells disclosure reveals fresh information about litigation risk not heretofore shown by an analysis of public information.

Third, we examine market reaction around the receipt date of a Wells notice. Managers may choose to disclose the receipt of Wells notice immediately after receipt. However, prompt Wells disclosure could also be a double-edged sword if the adverse stock price effects occur mainly for firms with high litigation risk, and managers do not want to signal this aspect prematurely to shareholders (Greenberg, 2008; Astarita, 2010). (Note 3) As such, the filings we study are primarily those of firms that chose to reveal the receipt of a Wells report, which produce negative consequences on the average. This analysis finds no significant market reaction over days -1 to 1 around the receipt date of a Wells notice for those firms that disclosed such receipt date in a later filing. This comports with the view that the receipt of a Wells notice is not contemporaneously known by public investors, other than through a channel such as a subsequent $8-\mathrm{K}$ or $10-\mathrm{K} / 10-\mathrm{Q}$ filing.

Our paper contributes uniquely in four ways. First, we provide guidance to help managers make informed decisions about whether to disclose the notice upon receipt in an 8-K or defer to a later filing. Our results make it clear that managers face an ethical challenge. This occurs because prompt disclosure of a Wells notice in an 8-K filing associates with negative returns for investors, whereas delayed disclosure in a $10-\mathrm{K}$ or $10-\mathrm{Q}$ does not. Second, our findings are relevant to the literature on market response to formal SEC proceedings and financial restatements (reviewed in Section 0.2). Without controls for Wells notices (often the first step in an SEC inquiry), those studies may have understated the overall effect. We show a significant effect occurs in response to the SEC's initial inquiry as revealed by a Wells notice, and that effect is increasingly negative in litigation risk. Third, we provide evidence on the price-sensitivity of a Wells disclosure. Regulators and others might consider such in an examination of the materiality criteria for disclosure upon the receipt of relevant information. Finally, we introduce refinements in the research approach that improve upon prior studies of the market effects of Wells notices.

Our study continues as follows. Section 0 discusses the Wells process and prior studies. Section 0 describes the sample and outlines the research approach. Section 0 presents the results, and Section 0 concludes.

\section{SEC Rules and Literature Review}

\subsection{The Wells Process and Wells Notice Disclosure}

A Wells notice issued by the SEC enforcement division (or the National Association of Securities Dealers) serves two objectives: it informs the company of findings made by SEC staff during a preliminary investigation; and where 
practicable and appropriate, it recommends that enforcement proceedings be commenced against the respondent. Having a Wells notice is not a necessity for a subsequent SEC accounting and auditing enforcement release (AAER) or a litigation action, however. For instance, when the SEC considers that immediate enforcement is necessary to protect investors, it may initiate an action and bypass the Wells process (SEC, 2011).

After receipt of a Wells notice, a prospective defendant has the option to respond to the SEC using a "Wells submission". Such submission gives the prospective defendant the opportunity to speak to the SEC before a decision is made on formal proceedings. A submission may point out factual inaccuracies in the staff's analysis, for example. Responding to a Wells notice, on the other hand, could harm a prospective defendant's position at the hearing and in later negotiations as a Wells submission is not privileged. A prospective defendant may also negotiate a settlement, and the SEC may terminate the investigation after considering a prospective defendant's Wells submission (Naftalis, 2002).

The SEC rules are vague on the disclosure of receipt of a Wells notice, and it is often left to the firm to decide whether and when to disclose. Regulation S-K, Item 103, which applies to 10-Qs and 10-Ks, requires firms to describe any material pending legal proceedings. However, a Wells notice is only a notification of a potential enforcement action rather than a "pending legal proceeding". Therefore, many argue that a Wells notice does not meet the legal standard for required disclosure. If a company intends to notify investors of a Wells receipt promptly, it can file an $8-\mathrm{K}$ although the rules for $8-\mathrm{K}$ do not address litigation disclosure directly. Nevertheless, there is a catchall provision in the $8-\mathrm{K}$ filing instructions for "other events" that a company considers important for investors, but this is also discretionary.

\subsection{Prior Research}

Several studies investigate the market consequences of an AAER action or shareholder litigation event. Feroz, Park and Pastena (1991) examine disclosures of disputed accounting, SEC investigations, and final settlement, and report a mean excess return of -12.9 percent on days -1 and 0 around the first disclosure of the disputed accounting and a further decrease of six percent on days -1 and 0 around the disclosure of the SEC investigation conditional on prior knowledge of the dispute. Nourayi (1994) documents a three-day cumulative mean excess return of -0.62 percent to SEC litigation releases and finds a more negative response to injunctive actions than administrative proceedings. Dechow, Sloan and Sweeney (1996) report a one-day mean excess return of -8.8 percent, an increase in the bid-ask spread, and a decline in analyst coverage around the disclosure of an AAER misstatement announcement. Karpoff, Lee, and Martin (2008a) find that the initial disclosure of an SEC or Department of Justice litigation or administrative action generates an excess return of -9.6 percent. Financial fraud also has long-lasting valuation effects: for example, Leng, Feroz, Cao, and Davalos (2011) document significantly negative abnormal returns for up to three years following AAERs, specifically, mean one-year, two-year, and three-year buy and hold excess returns after the AAER month of -13 percent, -24 percent and -25 percent, respectively. Additionally, some studies examine the market consequences of restatement announcements: for example, Palmrose, Richardson, and Scholz (2004) report a mean excess return of -9.2 percent over two days around the announcement. Finally, in related work on AAER actions, Correia (2014) finds that politically connected firms are less likely to be involved in AAER actions and face lower penalties if prosecuted, and Cao, Leng, Feroz, and Davalos (2015) find that investors reevaluate the credit risk of AAER firms following the regulatory sanctions imposed.

None of these studies, however, controls for the market impact of a Wells notice. This could be a relevant omission because an AAER action, shareholder litigation filing, or restatement announcement can follow a Wells notice, whose reaction around receipt or disclosure date could anticipate the negative effects of the subsequent event. (Note 4) If so, this means that the prior work understates the economic impact of the events studied. For example, informed investors might respond negatively to the increased use of income-increasing accounting choices several years before a formal restatement (Ettredge, Scholz, Smith, \& Sun, 2010), which could prompt an (undisclosed) Wells notice. Karpoff, Koester, Lee, and Martin (2014) provide further evidence of understatement and document that the most commonly-used data sources of events relating to misconduct (Securities Class Action Clearing House, SEC's AAER series on securities litigation, Government Accountability Office, and Audit Analytics on restatements) capture only a small portion of the price effects of the misconduct, as the databases ignore much relevant precursory information, including Wells notices; although Karpoff et al. (2014) do not analyze the investor impact of Wells notices, as we do here. (Note 5)

Two prior studies of investors' response to a Wells notice have tested and found negative excess returns around the date of a Wells disclosure in an SEC filing. Nelson, Gilley, and Trombley (2009) report a significant mean excess return of -2.59 percent on day 0 for 58 first-time Wells disclosures with receipt dates in 2002-2007; and Nainar, Rai 
and Tartarogul (2012) examine 77 first-time Wells disclosures in 8-K filings during 1999-2007 (mostly in 2004-2006) and report a cumulative mean market-adjusted excess return of -3.3 percent over days -1 to 1 . These studies, therefore, suggest a negative response to the first-time disclosure of approximately three percent. However, that response should also depend on whether the filing is a first-time $8-\mathrm{K}$ filing or a $10-\mathrm{K}$ or $10-\mathrm{Q}$ filing, as the latter filings contain substantially more unrelated information, which could obscure the news content of a Wells notice disclosure within such filings. Accordingly, we state our first hypothesis as:

H1: That investors' response is more negative for a first time Wells notice in an 8-K filing compared to a 10-K/10-Q filing versus the null hypothesis of no difference in investors' response.

We also contribute, relative to the prior work, in a more important way by introducing two critical features into our research design. These features control for possible bias and help us understand better why investors might respond negatively to a Wells notice. First, neither study controls for the bias that could occur because the results derive from Wells disclosers only and do not consider the possibly differential market effects of Wells non-disclosers, which could be more serious given their propensity for non-disclosure. We assess this issue based on the attributes of firms with an AAER action but without a Wells disclosure, as these firms could reasonably be expected to have received an earlier Wells notice. Second, neither prior study identifies the market effect of news about litigation risk in a Wells disclosure incremental to what the market would assess as litigation risk based on public information contemporaneous with the disclosure. This issue is also critical because the market reaction around a Wells disclosure could differ based on whether the notice merely identifies a company whose litigation risk is judged as higher or lower based on public information or telegraphs additional detail such as litigation risk heretofore unknown to investors. Research by Kim and Skinner (2012) helps us develop a model of litigation risk based on public information to control for this possibility. By addressing these issues, we can test for a relation between investors' response and Wells notice related litigation risk, which is our second hypothesis. We state this hypothesis as:

H2: That investors' response to Wells notice disclosure varies negatively with the litigation risk revealed in the notice versus the null hypothesis that investors' response does not vary with litigation risk.

In short, we contribute uniquely and significantly to the literature by introducing critical features into our research design not considered in the prior studies, which enable us to test a litigation risk hypothesis to understand what might prompt investors to react negatively to a Wells disclosure. Investors in an efficient market should develop informed expectations about litigation risk conditional on a Wells notice disclosure that differ predictably on the basis of public information and predictable future outcomes. See, also, Nourayi (1994) in the context of AAER actions, and Griffin, Grundfest, and Perino (2004) in the context of private securities class actions.

\section{Data and Research Approach}

\subsection{Data and Sample}

We first extract from DirectEDGAR the text surrounding all mentions of "Wells notice" or "Wells letter" directed at a company or company officer from the 10-K, 10-Q, and 8-K filings in 2001-2010. Based on that text, we categorize each extract as a first-time or subsequent Wells disclosure. Subsequent Wells disclosures in most cases discuss similar information to the first-time disclosure plus firms' follow-up actions if any. (Note 6) When a firm receives two or more unrelated Wells notices, we treat them as separate events and code each as a first mention. Second, we record the SEC filing date and the date of receipt of the Wells notice, if available. Third, we identify whether any of the Wells disclosures indicates a subsequent investigation, categorized as an AAER action or shareholder litigation, and the date associated with the subsequent investigation. We use the Haas Center for Financial Reporting and Management $(C F R M)$ litigation data set to identify these investigations. These steps determine whether a firm makes a timely or delayed disclosure of Wells receipt and whether a subsequent AAER action or shareholder litigation event occurs promptly or with a delay following filing date or receipt date. We also use the Audit Analytics financial restatement data set to identify subsequent financial restatements; as such events might further condition investors' initial response. To profile the sample firms and develop models of disclosure likelihood and ex-ante litigation risk based on contemporaneous public information, we extract additional data from Compustat and CRSP. Finally, we obtain stock return, trading volume, and bid-ask spread data from CSRP for disclosure days -20 to 20 to test for a response using those variables.

Table 1 summarizes the sample characteristics. Our search identifies 603 Wells disclosures in SEC filings (Panel A), including 119 first-time disclosures. Eighty of these show up in an 8-K within four or five days of Wells receipt date. These disclosures distribute reasonably evenly over the years examined (2001-2009) except for smaller numbers in 2001-2003 (2001-2002 are combined for convenience). For example, over 2004-2009, the mean number of notices is 
93.7 per year with a standard deviation of 10.6. Panel B of Table 1 compares the characteristics of Wells disclosers with firms in the CFRM data set with AAER firms without a Wells disclosure (AAERs without Wells). (Note 7) Relative to AAERs without Wells firms, Wells disclosers are generally larger in size (log at, log mktcap), more profitable (ib/at), trade more often (log tradvol), and have greater analyst coverage (ibes). They are also less capital intensive (capx/at) and have lower risk characteristics (leverage, ibes stdev, roavolat). In general, we would expect these differences as not all Wells disclosers experience a formal investigation such as an AAER, and AAER firms are smaller with higher risk characteristics. While these data are interesting separately, we also consider the characteristics of AAERs without Wells firms in testing whether the exclusion of non-Wells disclosers makes a difference to our analysis. We discuss this in Section 0.

Panel B of Table 1 also compares first-time 8-K and first-time 10-K/10-Q disclosures but shows no difference across any of the characteristics. Wells disclosure firms also concentrate in the manufacturing, wholesale, and financial industries (Panel C) and weight more to finance and insurance firms than AAERs without Wells firms or the Compustat population (based on SIC one-digit industry code $=6$ ). This latter finding is not surprising, however, as many of the more recent Wells notices target executive compensation, subprime, and other issues related to financial services.

Table 1. Wells disclosure sample characteristics

\begin{tabular}{|c|c|c|c|c|c|c|c|c|c|c|c|c|}
\hline \multicolumn{3}{|c|}{ Panel A: Source of Wells disclosure and timing } & Count & 2001-2002 & \multicolumn{3}{|c|}{2004} & 2005 & 2006 & 2007 & 2008 & 2009 \\
\hline \multirow[t]{2}{*}{$8-\mathrm{K}$} & First-tin & & 80 & 1 & 7 & \multicolumn{2}{|c|}{17} & 14 & 9 & 10 & 7 & 15 \\
\hline & Subsequ & & 63 & 0 & 0 & \multicolumn{2}{|c|}{11} & 13 & 13 & 13 & 3 & 10 \\
\hline \multirow[t]{2}{*}{$10-\mathrm{Q}$} & First-tin & & 28 & 1 & 0 & \multicolumn{2}{|c|}{3} & 7 & 2 & 3 & 5 & 7 \\
\hline & Subsequ & & 302 & 2 & 20 & \multicolumn{2}{|c|}{43} & 49 & 46 & 48 & 41 & 53 \\
\hline \multirow[t]{3}{*}{$10-\mathrm{K}$} & First-tin & & 11 & 1 & 2 & \multicolumn{2}{|c|}{2} & 1 & 2 & 1 & 2 & 0 \\
\hline & Subsequ & & 119 & 1 & 6 & \multicolumn{2}{|c|}{17} & 13 & 27 & 22 & 15 & 18 \\
\hline & All & & 603 & 6 & 35 & \multicolumn{2}{|c|}{93} & 97 & 99 & 97 & 73 & 103 \\
\hline \multicolumn{2}{|l|}{ Panel B: Descriptive } & $\log a t$ & $\log$ mktcap & $i b / a t$ & margin & dltt/at & capx/at & growth & $\begin{array}{c}\log \\
\text { tradvol }\end{array}$ & num ibes & ibes stdev & roavolat \\
\hline \multirow[t]{2}{*}{ All Wells } & $\mathrm{N}$ & 591 & 587 & 591 & 590 & 591 & 585 & 584 & 587 & 527 & 488 & 591 \\
\hline & Mean & 22.1879 & 21.6299 & -0.0247 & 0.3379 & 0.1624 & 0.0240 & 0.5937 & 32.7723 & 10.5674 & 0.0814 & 0.0800 \\
\hline \multirow[t]{2}{*}{ AAERs without Wells } & $\mathrm{N}$ & 641 & 643 & 637 & 643 & 639 & 612 & 638 & 643 & 483 & 400 & 637 \\
\hline & Mean & 20.2044 & 19.9260 & -0.0640 & 0.2982 & 0.2007 & 0.0439 & 0.5474 & 31.4522 & 8.0393 & 0.1194 & 0.1511 \\
\hline \multirow{3}{*}{$\begin{array}{l}\text { All Wells - AAERs } \\
\text { without Wells }\end{array}$} & Diff. & 1.983 & 1.704 & 0.039 & 0.0397 & -0.038 & -0.020 & 0.046 & 1.3201 & 2.5280 & -0.0380 & -0.071 \\
\hline & t-val. & 12.4245 & 11.8298 & 3.0699 & 0.9436 & -3.4458 & -8.7743 & 1.0843 & 9.7289 & 5.2704 & -1.9861 & -6.1883 \\
\hline & Signif. & $* * *$ & $* * *$ & ** & ns & $* * *$ & *** & ns & *** & $* * *$ & * & *** \\
\hline \multirow[t]{2}{*}{ First-time $8-\mathrm{K}$} & $\mathrm{N}$ & 77 & 78 & 77 & 77 & 77 & 77 & 77 & 78 & 71 & 77 & 77 \\
\hline & Mean & 21.8742 & 21.2265 & -0.0296 & 0.3534 & 0.1546 & 0.0224 & 0.5583 & 32.6229 & 9.8451 & 0.0763 & 0.0921 \\
\hline \multirow[t]{2}{*}{ First-time $10-\mathrm{K} / 10-\mathrm{Q}$} & $\mathrm{N}$ & 37 & 34 & 37 & 37 & 37 & 36 & 34 & 34 & 33 & 37 & 37 \\
\hline & Mean & 22.2991 & 21.8645 & -0.0072 & 0.4789 & 0.1521 & 0.0241 & 0.5424 & 32.8450 & 10.5758 & 0.0565 & 0.0775 \\
\hline First time 8-K - & Diff. & -0.4249 & -0.6379 & -0.0224 & -0.1256 & 0.0026 & -0.0017 & 0.0159 & -0.2221 & -0.7307 & 0.0198 & 0.0146 \\
\hline \multirow[t]{2}{*}{ First time $10-\mathrm{K} / 10-\mathrm{Q}$} & t-val. & -0.7940 & -1.3302 & -0.6522 & -0.7815 & 0.0721 & -0.2868 & 0.1556 & -0.4515 & -0.4619 & 0.7568 & 0.5169 \\
\hline & Signif. & ns & ns & ns & ns & ns & ns & ns & ns & ns & ns & ns \\
\hline Panel C: SIC one-digit & dustry class & & & & & & & & & & & \\
\hline Industry & & All & 0 & 1 & 2 & 3 & 4 & 5 & 6 & 7 & 8 & 9 \\
\hline First-time $8-\mathrm{K}$ & $\mathrm{N}$ & 80 & 0 & 2 & 7 & 16 & 0 & 7 & 34 & 14 & 0 & 0 \\
\hline & Percent & $100 \%$ & $0.00 \%$ & $2.50 \%$ & $8.75 \%$ & $20.00 \%$ & $0.00 \%$ & $8.75 \%$ & $42.50 \%$ & $17.50 \%$ & $0.00 \%$ & $0.00 \%$ \\
\hline AAERs without Wells & $\mathrm{N}$ & 620 & 7 & 34 & 87 & 192 & 36 & 52 & 79 & 95 & 21 & 17 \\
\hline & Percent & $100 \%$ & $1.13 \%$ & $5.48 \%$ & $14.03 \%$ & $30.97 \%$ & $5.81 \%$ & $8.39 \%$ & $12.74 \%$ & $15.32 \%$ & $3.39 \%$ & $2.74 \%$ \\
\hline Compustat & $\mathrm{N}$ & 100,443 & 327 & 9,759 & 12,842 & 18,929 & 9,203 & 6,601 & 26,716 & 11,701 & 2,883 & 1,482 \\
\hline & Percent & $100 \%$ & $0.33 \%$ & $9.72 \%$ & $12.79 \%$ & $18.85 \%$ & $9.16 \%$ & $6.57 \%$ & $26.60 \%$ & $11.65 \%$ & $2.87 \%$ & $1.48 \%$ \\
\hline
\end{tabular}

Panel A presents the sample distribution by the source of Wells disclosure $(8-\mathrm{K}, 10-\mathrm{Q}$, or $10-\mathrm{K})$ and the timing of the disclosure (first-time or subsequent disclosure) from 2001 to 2009. First-time disclosure = first mention of Wells notice by company, Subsequent disclosure $=$ subsequent mention of Wells notice by company. Panel B presents the mean of company characteristics for the following samples. All Wells = all Wells disclosure obs., AAERs without Wells = AAER obs. but no disclosure of a Wells notice, First-time 8-K = first-time Wells notice in 8-K, First-time 10-K/10-Q = first-time Wells notice in 10-K or 10-Q, Compustat $=$ all firm-year observations in Compustat database from 2001 to 2009. See Appendix A for variable definitions. Except as stated otherwise, all variables relate to the fiscal year prior to the year of Wells disclosure. $* * *=$ significant at $<.001$, **=significant at $<.01$. * =significant at <.05, ns=not significant. Panel $\mathrm{C}$ compares the sample distribution of First-time 8-K Wells to AAERs without Wells and Compustat firms by one-digit SIC number: $0=$ Agriculture, Forestry, and Fishing, $1=$ Mining and Construction, 2 = Light Manufacturing, 3 = Heavy Manufacturing, $4=$ Transportation and Public Utilities, $5=$ Wholesale and Retail Trade, $6=$ Finance, Insurance, and Real Estate, $7=$ Services, $8=$ Health, $9=$ Unclassified.

\subsection{Research Approach}

We use an event-study approach, which is appropriate because the item of interest - disclosure of Wells notice or receipt of Wells notice - distributes broadly across time and is date-stamped by the Commission or recipient company. We align the Wells disclosure date or Wells receipt date in event time and measure investors' response as 
market-adjusted excess stock return on day $t$ relative to day 0 , defined as the SEC filing date or Wells receipt date. We define market-adjusted excess stock return as the return on stock $i$ for day $t$ minus the return on the value-weighted index of stocks in the CRSP database. As a robustness check, we repeat our tests of investor response using the Fama-French/Carhart four-factor model (Carhart, 1997). In addition, we examine daily-adjusted trading volume and quoted daily bid-ask spread as additional measures of information response. We define adjusted trading volume as volume for day $t$, times 50 percent for a NASDAQ company due to dealer trading (Anderson \& Dyl, 2005 ) divided by common shares outstanding at day $t$ relative to filing date or receipt date. We define quoted daily bid-ask spread as (ask price - bid price) $\div[$ (ask price + bid price)/2] for day $t$. One feature of an event study is that it may be difficult to attribute investors' response around the event day to the Wells event itself because other information could trigger the response. We, therefore, compare investors' responses to first-time 8-K filings with 10-K/10-Q filings. Relative to $10-\mathrm{Ks}$ or $10-\mathrm{Qs}, 8-\mathrm{K}$ filings should be less contaminated by other news and, therefore, associate with a more negative price response around a Wells disclosure. The model below also checks for earnings announcements in the Wells disclosure event window.

We then extend the event study and conduct a regression analysis to test for a relation between excess stock return over 8-K event days $-1,0$, and $1\left(\right.$ xret $\left._{t}\right)$ and Wells notice related litigation risk after controlling for other potential determinants of excess market return. We state the model as follows: (Note 8)

$$
\begin{aligned}
& \text { xret }_{t}=\alpha_{1}+\alpha_{2} \text { litigation }_{t}+\alpha_{3} \text { earnings announcement }_{t}+\alpha_{4} \text { earnch }_{t}+\alpha_{5} \text { size }_{t-1}+ \\
& \alpha_{6} \text { profitability }_{t-1}+\alpha_{7} \text { growt }_{t-1}+\alpha_{8} \text { leverage }_{t-1}+\alpha_{9} \text { investment }_{t-1}+\alpha_{10} \text { imr }_{t}+\varepsilon_{t}
\end{aligned}
$$

Specifically, Eq. (1) uses the variable litigation to proxy for Wells notice related litigation risk at disclosure date $t$. We expect a negative coefficient for litigation, which implies that the excess return around a Wells disclosure (xret) varies negatively with litigation risk at date $t$ incremental to a fixed effect in $\alpha_{1}$ and those effects captured by the other variables. We proxy for Wells related litigation risk in two ways. First, we specify litigation based on contemporaneous information other than the Wells disclosure, as investors should condition their response on such. We predict ex-ante litigation risk based on Kim and Skinner (2012), where we apply the parameters in Eq. (2) of Table 7 of that study to the same lagged values of the variables for the firms in our sample. We then rank firms from high to low based on this predicted value on a yearly basis. (Note 9) As a robustness check, we use a simpler measure of ex-ante litigation risk by splitting the Wells sample into those firms with AAER or shareholder litigation in the previous five years versus those without prior litigation. Second, we specify litigation in relation to a subsequent litigation event and denote that as delayed litigation or timely litigation, where one year following the Wells disclosure date establishes the cut-off for timeliness.

These proxies allow us to test further our second (and main) hypothesis, that is, if a Wells disclosure telegraphs litigation risk information to investors beyond what is already known publicly, the litigation coefficient should be increasingly negative and significant as we switch the proxy from ex-ante to delayed to timely litigation risk. We should also observe the same pattern for mean xret cumulated over disclosure days -1 to 1 when we partition the sample into three groups, namely, firms with high ex-ante litigation risk, delayed litigation, and timely litigation.

Model 1 also includes the control variables earnings announcement (1 for days with an earnings announcement in days -2 to 2, otherwise 0), earnchg (epspx $x_{t-1}-e p s p x_{t-2}$ for days with an annual earnings announcement and epspxq $q_{t-1}-$ epspxq $q_{t-5}$ for days with a quarterly earnings announcement, scaled by the number of shares outstanding at the end of the previous year or quarter), and one-year lagged measures for size $=\left(\log\right.$ at $\left.x 10^{6}\right)$, profitability $($ ib/at $)$, growth (book value of equity, ceq, divided by total market capitalization, csho $x$ prcc $f)$, leverage $=($ dltt/at $)$, and investment $=$ (capx/at). As small stocks tend to experience higher returns than large stocks, we include size (log $a t)$ to capture this effect, although some prior literature considers size as a proxy for litigation risk. Earnings announcement and earnchg control for the timing and sign of earnings news on day $t$, profitability captures financial strength, and leverage controls for firms' financial risk or news related to financing decisions. Lastly, we include growth and investment to capture possible news related to growth prospects and investment decisions.

Finally, Eq. (1) includes the variable imr. This variable controls for possible bias in the $\alpha_{2}$ coefficient because the regression results derive from Wells disclosers only and do not consider the possibly differential effects on $\alpha_{2}$ of Wells non-disclosers, which could be more serious, given their propensity for non-disclosure. We follow the two-stage approach of Heckman (1979) and calculate an inverse Mills ratio (imr) for each sample observation as of disclosure day $t$ based on a first-stage model of the likelihood that a Wells recipient makes a Wells disclosure. (Note 10) We then test the hypothesis that the model (1) $i m r$ coefficient $\alpha_{10}$ differs from zero, which if non-zero would be evidence that $\alpha_{2}$ in Eq. (1) could differ for Wells disclosers versus non-Wells disclosers.

We specify the first-stage model as follows, where the dependent variable $d s c l$ equals 1 for a Wells discloser and 0 
for an AAER company but not a Wells discloser:

$$
\begin{aligned}
& d s c l=\beta_{1}+\beta_{2} \text { retvolat }_{t}+\beta_{3} \text { mktcap }_{t-1}+\beta_{4} \log \text { cshrs }_{t-1}+\beta_{5} \log \text { tradvol }_{t-1}+\beta_{6} \text { leverage }_{t-1} \\
& +\beta_{7} \text { growth }_{t-1}+\beta_{8} \text { loss_ind }_{t-1}+\beta_{9} \text { earnchg_ind }_{t-1}+\beta_{10} \text { roavolat }_{t-1}+\beta_{11} \text { industry }+\varepsilon_{t},
\end{aligned}
$$

where retvolat $=$ standard deviation of monthly stock return over 60 months ending the month before the SEC filing date $t$, and one-year lagged measures for mktcap $=$ natural $\log$ of market capitalization (log mktcap), $\log$ cshrs $=$ natural $\log$ of the number of common shareholders, log tradvol = natural log of annual trading volume, leverage $=$ long-term debt divided by total assets, growth $=$ book value of equity divided by total market capitalization, loss $=1$ if the firm reports a loss at end of year $t-1$, otherwise 0, earnchg_ind $=1$ if epspx at end of year $t-1$ is greater than epspx at the end of year $t-2$, otherwise 0 , roavolat $=$ standard deviation of return on assets over past five years to $t-1$, and industry $=1$ if the company is in the biotech (SIC codes 2833-2836 and 8731-8734), computer (3570-3577 and 7370-7374), electronics (3600-3674), or retail (5200-5961) industries, otherwise 0.

We motivate this first-stage model by assuming that while Wells disclosers and non-disclosers share common risk and other factors they may also differ in the intensity of the measures that apply to those factors, such as those indicated in Panel B of Table 1 (e.g., mktcap, roavolat). We chose our variables from prior research, in particular, Francis, Philbrick and Schipper (1994) (who define the industry variable) and Kim and Skinner (2012) (who develop their various models from the prior literature), and from our analysis in Panel B of Table 1. (Note 11) Under the Heckman (1979) approach, the imr variable in Eq. (1) then reflects an assessment of Wells disclosure likelihood based on the estimated Eq. (2) coefficients applied to company-specific values for each variable.

A final aspect of our research approach is that subsequent litigation may not be independent of a company's decision to disclose the receipt of a Wells notice, as that disclosure may influence the SEC's decision to proceed with a formal investigation or shareholders' views to initiate private litigation. Research is mixed, however, on whether disclosure increases (Francis et al. 1994) or decreases (Skinner, 1994) the likelihood or cost of subsequent litigation. In addition, Field, Lowry and Shu (2005) find no difference in the frequency of disclosure of earnings warnings for firms sued and not sued in class action securities litigation. However, they also report that early disclosure could lower litigation risk. (Note 12) This is an interesting finding, for if applicable in the context of a Wells disclosure, this makes our approach more conservative, because it makes it more difficult to reject the hypothesis of an increasingly negative investor response around Wells disclosure days -1 to 1 conditional on subsequent litigation, especially for first-time disclosures in 8-K filings.

\section{Results}

\subsection{Excess Stock Return}

Table 2 presents the results for excess stock return in three panels: Panel A, first-time Wells disclosures partitioned by the source of disclosure, namely, an $8-\mathrm{K}$ or a 10-K/10-Q; Panel B, first-time 8-K Wells disclosures partitioned between high and low ex-ante litigation risk; and Panel $\mathrm{C}$, first-time $8-\mathrm{K}$ Wells disclosures partitioned by timely and delayed litigation. We focus on first-time disclosures, as these should be more newsworthy to investors. Within each panel, we report the mean excess return and a two-tailed $t$ test of the significance of the sum of the means over event days -1 to $1,-2$ to 2 , and -2 to 30 versus the null of zero and, where appropriate, a two-tailed t test of a negative mean difference versus the null of zero mean difference.

First, Panel A shows that first-time Wells disclosures associate with a negative market response over days -1 to 1 when the source of disclosure is an $8-\mathrm{K}$ (mean $=-1.84 \%, \mathrm{t}$ val. $=-1.3210$ ) but not when the source is a $10-\mathrm{K}$ or $10-\mathrm{Q}$ $($ mean $=1.32 \%, \mathrm{t}$ val. $=1.2338)$. Panel A also shows a significant difference in the mean $8-\mathrm{K}$ and $10-\mathrm{K} / 10-\mathrm{Q}$ response over days -1 to 1 (diff. $=-3.16 \%, \mathrm{t}$ val. $=-2.1736)$ and days -2 to $2($ diff. $=-2.81 \%, \mathrm{t}$ val. $=-1.7597)$. The cumulative difference over days -2 to 30 is also negative and significant. These results support $H 1$, that is, we observe a more negative response to Wells disclosures in 8 -Ks versus $10-\mathrm{K} / 10-\mathrm{Qs}$.

Second, for first-time 8-K disclosures, Panel B tests whether investors react differently based on a risk assessment derived from public information. We split the sample into high and low ex-ante litigation risk as per Kim and Skinner (2012). While both groups show a significantly negative response over days -1 to 1 , the difference is not significant (diff. $=-0.05 \%, \mathrm{t}$ val. $=-0.0301$ ). The difference is not significant for the other return intervals also. This suggests that conditional on a Wells disclosure, investors do not distinguish between high and low ex-ante litigation risk. One reason is that prices already capture such risk information, and one would expect this given ex-ante litigation risk derives from historical data. We also examine an alternative measure of $e x$-ante litigation risk based on the presence of prior AAER or shareholder litigation in the past five years. This variable, too, does not indicate that investors distinguish between high and low ex-ante litigation risk at Wells disclosure date. 
Table 2. Daily market-adjusted excess returns around a Wells disclosure

\begin{tabular}{|c|c|c|c|c|c|c|c|}
\hline \multicolumn{8}{|c|}{ Panel A: Comparison between first-time 8-K disclosers and first-time 10-K/10-Q disclosers } \\
\hline & First-time & & First time & & & t-val. & \\
\hline Trading day & $8-\mathrm{K}$ & $\mathrm{N}$ & $10-\mathrm{K} / 10-\mathrm{Q}$ & $\mathrm{N}$ & Diff. & Diff. & Signif. \\
\hline-2 & 0.0013 & 80 & -0.0051 & 39 & & & \\
\hline-1 & 0.0034 & 80 & 0.0086 & 39 & & & \\
\hline 0 & -0.0117 & 80 & 0.0048 & 39 & & & \\
\hline 1 & -0.0102 & 80 & -0.0002 & 39 & & & \\
\hline 2 & 0.0021 & 80 & 0.0049 & 39 & & & \\
\hline Sum $(-1$ to 1$)$ & -0.0184 & & 0.0132 & & -0.0316 & -2.1736 & $* *$ \\
\hline t-val. (2-tailed) vs. 0 & -1.3210 & ns & 1.2338 & ns & & & \\
\hline Sum (-2 to 2$)$ & -0.0150 & & 0.0131 & & -0.0281 & -1.7597 & $*$ \\
\hline t-val. (2-tailed) vs. 0 & -0.9761 & ns & 0.8886 & $\mathrm{~ns}$ & & & \\
\hline Sum (-2 to 30$)$ & -0.0159 & & 0.0598 & & -0.0757 & -2.8833 & $* * *$ \\
\hline t-val. (2-tailed) vs. 0 & -0.3393 & ns & 1.7951 & $* *$ & & & \\
\hline
\end{tabular}

\begin{tabular}{|c|c|c|c|c|c|c|c|}
\hline \multicolumn{8}{|c|}{ Panel B: Comparison between first-time 8-K disclosers with high versus low ex-ante litigation risk } \\
\hline \multirow[b]{3}{*}{ Trading day } & \multirow{3}{*}{$\begin{array}{r}\text { First-time } 8-\mathrm{K} \\
\text { with high ex-ante } \\
\text { litigation risk }\end{array}$} & & \multirow{3}{*}{$\begin{array}{r}\text { First-time } 8-\mathrm{K} \\
\text { with low ex-ante } \\
\text { litigation risk }\end{array}$} & \multirow[b]{3}{*}{$\mathrm{N}$} & \multirow[b]{3}{*}{ Diff. } & \multirow{3}{*}{$\begin{array}{l}\text { t-val. } \\
\text { Diff. }\end{array}$} & \multirow[b]{3}{*}{ Signif } \\
\hline & & & & & & & \\
\hline & & $\mathrm{N}$ & & & & & \\
\hline-2 & 0.0040 & 37 & -0.0050 & 38 & & & \\
\hline-1 & -0.0030 & 37 & -0.0022 & 38 & & & \\
\hline 0 & -0.0114 & 37 & -0.0118 & 38 & & & \\
\hline 1 & -0.0108 & 37 & -0.0107 & 38 & & & \\
\hline 2 & 0.0037 & 37 & -0.0007 & 38 & & & \\
\hline Sum $(-1$ to 1$)$ & -0.0252 & & -0.0247 & & -0.0005 & -0.0301 & ns \\
\hline t-val. (2-tailed) vs. 0 & -2.2194 & $* *$ & -2.1628 & $* *$ & & & \\
\hline Sum (-2 to 2$)$ & -0.0212 & & -0.0297 & & 0.0085 & 0.6607 & ns \\
\hline t-val. (2-tailed) vs. 0 & -1.3194 & $\mathrm{~ns}$ & -2.3469 & $* *$ & & & \\
\hline Sum (-2 to 30$)$ & -0.0009 & & -0.0002 & & -0.0007 & -0.7049 & ns \\
\hline t-val. (2-tailed) vs. 0 & -0.9516 & ns & -0.2301 & ns & & & \\
\hline
\end{tabular}

Panel C: Comparison between first-time 8-K disclosers with timely litigation and first-time 8-K disclosers with delayed litigation

\begin{tabular}{|c|c|c|c|c|c|c|c|}
\hline Trading day & $\begin{array}{r}\text { First-time } 8-\mathrm{K} \\
\text { with timely } \\
\text { litigation }\end{array}$ & $\mathrm{N}$ & $\begin{array}{r}\text { First-time } 8-\mathrm{K} \\
\text { with delayed } \\
\text { litigation }\end{array}$ & $\mathrm{N}$ & Diff. & $\begin{array}{l}\text { t-val. } \\
\text { Diff. }\end{array}$ & Signif. \\
\hline-2 & -0.0024 & 23 & 0.0008 & 19 & & & \\
\hline-1 & -0.0130 & 23 & 0.0024 & 19 & & & \\
\hline 0 & -0.0143 & 23 & -0.0160 & 19 & & & \\
\hline 1 & -0.0180 & 23 & -0.0036 & 19 & & & \\
\hline 2 & 0.0017 & 22 & -0.0029 & 19 & & & \\
\hline Sum (-1 to 1$)$ & -0.0454 & & -0.0172 & & -0.0281 & -2.2937 & $* *$ \\
\hline t-val. (2-tailed) vs. 0 & -3.1699 & $* * *$ & -1.3133 & ns & & & \\
\hline $\operatorname{Sum}(-2$ to 2$)$ & -0.0461 & & -0.0194 & & -0.0267 & -2.2417 & $* *$ \\
\hline t-val. (2-tailed) vs. 0 & -2.8173 & $* * *$ & -1.3258 & ns & & & \\
\hline Sum (-2 to 30$)$ & -0.0484 & & -0.0265 & & -0.0219 & -0.7522 & ns \\
\hline t-val. (2-tailed) vs. 0 & -1.8941 & $*$ & -1.0318 & ns & & & \\
\hline
\end{tabular}

This table shows the mean market-adjusted excess return and the sum of mean excess return over event days -2 to 2 . Panel $\mathrm{A}$ compares first-time 8-K and first-time 10-K/10-Q Wells disclosures. Panel B compares first-time Wells disclosures partitioned on high versus low ex-ante litigation risk, where ex-ante litigation risk is estimated using Eq. (2) of Kim and Skinner (2012). Panel C compares first-time 8-K Wells disclosures partitioned on timely versus delayed litigation. Timely litigation occurs within 12 months of a Wells notice disclosure; Delayed litigation occurs after 12 months but within 5 years of Wells notice disclosure. Market-adjusted excess stock return $=$ the return on stock $i$ for day $t$ minus the return on the value-weighted index of stocks in the CRSP database, where $t$ is relative to the day of a Wells disclosure. $*^{* *}=$ significant at $<.01, * *=$ significant at $<.05, *=$ significant at $<.10, \mathrm{~ns}=$ not significant. 
Third, Panel C compares first-time 8-K disclosers with timely litigation and first-time 8-K disclosers with delayed litigation. This panel shows that first-time $8-\mathrm{K}$ disclosers with timely litigation elicit a significantly negative market response over days -1 to 1 (mean $=-4.54 \%, \mathrm{t}$ val. $=-3.1699)$ and days -2 to $2($ mean $=-4.61 \%, \mathrm{t}$ val. $=-2.8173)$. For Wells disclosers with delayed litigation, we also observe a less negative market response, but this is not significant for the day -1 to $1($ mean $=-1.72 \%, \mathrm{t}$ val. $=-1.3133)$ and the day -2 to $2($ mean $=-1.94 \%, \mathrm{t}$ val. $=-1.3258)$ intervals. Panel $\mathrm{C}$ further shows a significant difference in the mean market response for timely and delayed litigation over days -1 to 1 (diff. $=-2.81 \%$, $\mathrm{t}$ val. $=-2.2937)$ and days -2 to $2($ diff. $=-2.67 \%, \mathrm{t}$ val. $=-2.2417)$. (Note 13$)$

In untabulated analysis, we also examine whether the preceding results might differ qualitatively when we assess three-day excess stock return based on the Fama-French/Carhart four-factor model (Carhart 1997). The results are virtually identical for all panels of Table 2 . For example, $8-\mathrm{K}$ disclosers with timely litigation elicit a significantly negative market response over days -1 to $1($ mean $=-4.60 \%, \mathrm{t}$ val. $=-3.1894)$ and days -2 to $2($ mean $=-4.60 \%, \mathrm{t}$ val . $=-2.7821)$. For Wells disclosers with delayed litigation, we also observe a smaller negative market response, which is significant for both days -1 to 1 (mean $=-2.30 \%, \mathrm{t}$ val. $=-1.6311)$ and days -2 to 2 (mean $=-2.70 \%, \mathrm{t}$ val. $=$ -1.8238).

We also ask whether the firms with high (low) ex-ante litigation risk are also firms with (without) subsequent litigation. We find only limited overlap. For example, of the 42 firms with subsequent AAER or shareholder litigation, 48 percent have high ex-ante litigation risk based on the Kim and Skinner (2012) model; and of the 38 firms without subsequent AAER or shareholder litigation high ex-ante litigation risk, the model predicts that 50 percent have low ex-ante litigation risk. In short, the differential responses we observe are not primarily driven by a few (outlier) firms.

Figure 1 plots certain of the data in Table 2 to illustrate the negative market response around an 8-K Wells disclosure and to support further the view that investors' response reflects litigation risk. This figure plots mean excess return for days $-1,0$, and 1 , and the three-day mean excess return over -1 to 1 for four partitions of first-time 8-K disclosers. It shows a negative trend starting with first-time $8-\mathrm{K}$ disclosers (first group), followed by first-time 8 -K disclosers with high ex-ante litigation risk (second group), then first-time 8-K disclosers with delayed litigation (third group) and, finally, first-time 8-K disclosers with timely litigation (fourth group). The finding that investors' response to the third and fourth groups exceeds negatively the response to the first and second groups is evidence that Wells notices impart unique information about litigation risk not known to investors through an analysis of public information.

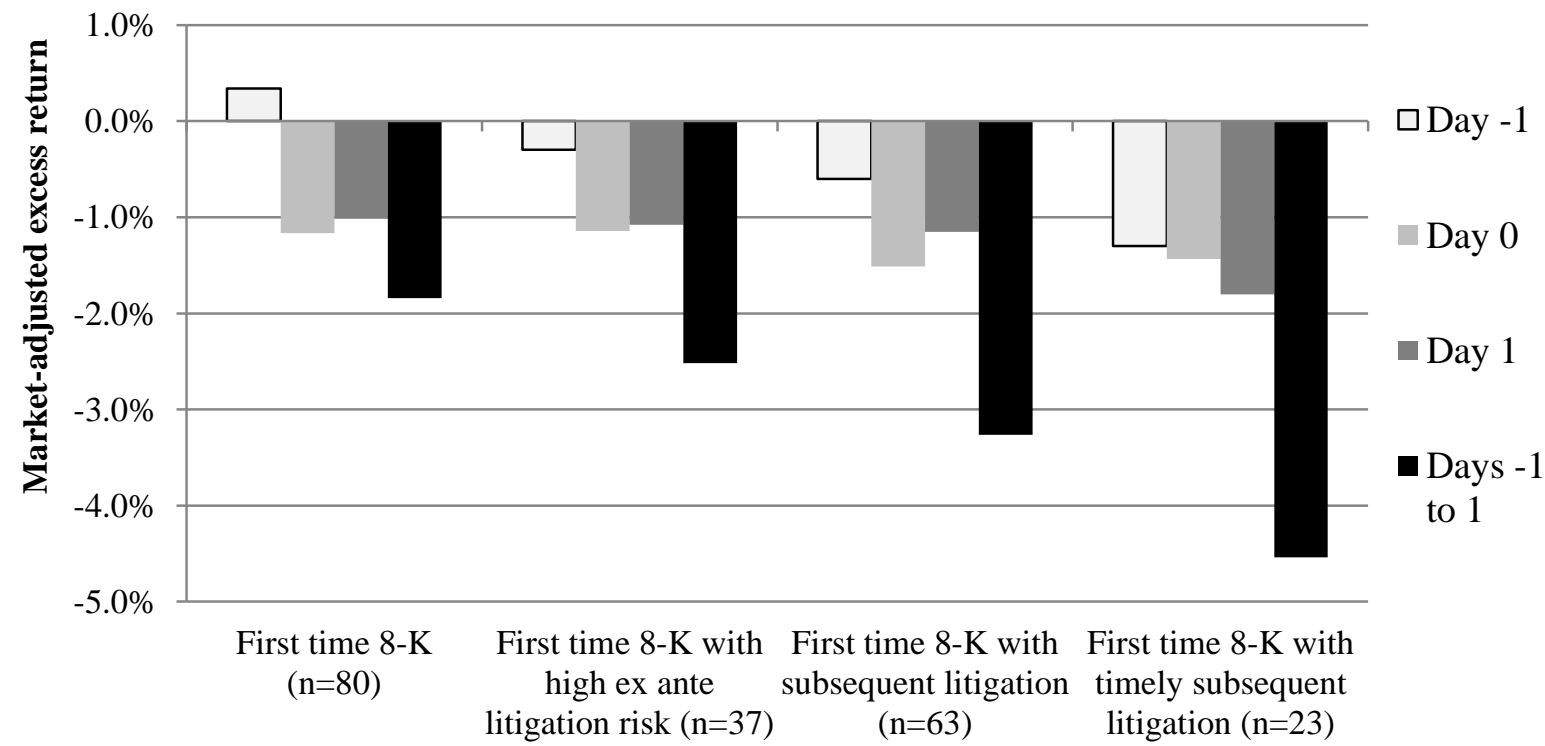

\section{Wells disclosure litigation risk}

Figure 1. Market-adjusted excess returns around a first-time 8-K Wells disclosure

This figure plots the daily market-adjusted excess returns around a first-time 8-K Wells disclosure for four sample partitions: (1) First time 8-Ks, (2) First time 8-Ks with high ex-ante litigtion risk, (3) First time 8-Ks with subsequent 
litigation (subsequent litigation), and (4) First time 8-Ks with timely subsequent litigation (timely litigation). See Appendix A for definitions of the variables.

To summarize, these results document a significant negative reaction to first-time Wells disclosures that differs based on the filing form and litigation risk, where the three-day negative stock reaction around event day is driven largely by first-time disclosures in 8 -K filings, which we presume are the least contaminated by other news. These results therefore support $H 1$ and $H 2$. We investigate the effects of litigation risk further in the next sub-section (0) using regression analysis.

Finally, we consider whether investors might condition their reaction to a Wells disclosure on a subsequent financial restatement, since that too could proxy for litigation risk. To conduct this test, we match our first-time Wells disclosure sample to Audit Analytics' financial restatement data set, which contains detailed restatement information from 2001 to 2010. We define a relevant subsequent restatement as one where the restatement occurs after the Wells disclosure date and Audit Analytics refers to the same event as the Wells disclosure. Untabulated results show a significant cumulative mean excess return over Wells disclosure days -1 to 1 of -2.11 percent for 36 first-time 8 -K Wells disclosures followed by a relevant restatement, compared to first-time 8-K Wells disclosures in general (-1.80\%, Table 2, Panel A). However, 16 of the 36 restatement cases also experience timely SEC or shareholder litigation, which likely contributes to this negative return, which is -4.54 percent for the timely litigation group as a whole (Table 2, Panel C). Hence, investors' response to a Wells disclosure may reflect some information about a possible restatement, which, presumably, is incremental to any later response around the restatement date itself, which has been the primary focus of the prior literature on the market effects of restatements (Section 0 ).

\subsection{Regression Analysis of Excess Stock Return}

This sub-section summarizes the regression relation between investors' response to a Wells disclosure and litigation risk, controlling for other variables that might influence that response, namely, earnings announcement effects, size, profitability, growth, leverage, and capital investments, and for possible coefficient bias because the Wells sample reflects Wells notice disclosers only and not all Wells notice recipients. Specifically, we regress market-adjusted excess stock return over days -1 to 1 for first-time $8-\mathrm{K}$ disclosers on a proxy for litigation risk, up to seven other factors that might explain or condition investors' response on Wells disclosure date, and a control for selection bias. Model 1 states the regression and the variables. Table 3 summarizes the results.

Table 3. Regression relation between investors' response to a Wells disclosure and litigation risk

\begin{tabular}{lccc}
\hline Panel A: First-stage regression to explain a company's decision to disclose a Wells notice & \\
& Coeff. & z-val & Sig. \\
\hline Intercept & -4.697 & -8.08 & $* * *$ \\
retvolat & 1.118 & 1.95 & $*$ \\
$\log$ mktcap & 0.201 & 7.04 & $* * *$ \\
$\log$ cshrs & -0.081 & -3.87 & $* * *$ \\
$\log$ tradvol & 0.054 & 2.36 & $* *$ \\
leverage & -0.618 & -2.82 & $* * *$ \\
growth & 0.014 & 0.24 & $\mathrm{~ns}$ \\
loss & 0.144 & 1.45 & $\mathrm{~ns}$ \\
earnchg_ind & 0.144 & 1.73 & $* *$ \\
roavolat & -0.786 & -2.88 & $* * *$ \\
industry & -0.239 & -2.66 & $* * *$ \\
\hline
\end{tabular}

See the next page for Panel B. 


\begin{tabular}{|c|c|c|c|c|c|c|c|c|c|c|}
\hline Statistic & $\begin{array}{l}\text { Coeff. } \\
\text { (t-val.) }\end{array}$ & $\begin{array}{l}\text { Coeff. } \\
\text { (t-val.) }\end{array}$ & $\begin{array}{l}\text { Coeff. } \\
\text { (t-val.) }\end{array}$ & $\begin{array}{l}\text { Coeff. } \\
\text { (t-val.) }\end{array}$ & $\begin{array}{l}\text { Coeff. } \\
\text { (t-val.) }\end{array}$ & $\begin{array}{l}\text { Coeff. } \\
\text { (t-val.) }\end{array}$ & $\begin{array}{l}\text { Coeff. } \\
\text { (t-val.) }\end{array}$ & $\begin{array}{l}\text { Coeff. } \\
\text { (t-val.) }\end{array}$ & $\begin{array}{l}\text { Coeff. } \\
\text { (t-val.) }\end{array}$ & $\begin{array}{l}\text { Coeff. } \\
\text { (t-val.) }\end{array}$ \\
\hline Regression \# & (1) & (2) & (3) & (4) & (5) & (6) & (7) & (8) & (9) & (10) \\
\hline Intercept & $\begin{array}{l}-0.045 \\
(-1.36)\end{array}$ & $\begin{array}{l}-0.029 \\
(-0.88)\end{array}$ & $\begin{array}{l}-0.036 \\
(-0.98)\end{array}$ & $\begin{array}{l}-0.048 \\
(-1.48)\end{array}$ & $\begin{array}{l}-0.031 \\
(-0.96)\end{array}$ & $\begin{array}{l}-0.041 \\
(-1.11)\end{array}$ & $\begin{array}{r}-0.062^{* *} \\
(-2.52)\end{array}$ & $\begin{array}{l}-0.049 \\
(-1.09)\end{array}$ & $\begin{array}{r}-0.060^{* * *} \\
(-2.40)\end{array}$ & $\begin{array}{l}-0.050 \\
(-1.12)\end{array}$ \\
\hline litigation & $\begin{array}{r}-0.007 * * * \\
(-2.74)\end{array}$ & & & $\begin{array}{r}-0.007 * * \\
(-2.49)\end{array}$ & & & $\begin{array}{r}-0.006 \\
(-0.81)\end{array}$ & $\begin{array}{l}-0.006 \\
(-0.74)\end{array}$ & $\begin{array}{l}-0.005 \\
(-0.70)\end{array}$ & $\begin{array}{l}-0.005 \\
(-0.65)\end{array}$ \\
\hline $\begin{array}{l}\text { timely litigation } \\
\text { delayed litigation }\end{array}$ & & $\begin{array}{r}-0.009^{*} \\
(-1.70)\end{array}$ & $\begin{array}{r}-0.009^{* *} \\
(-2.12) \\
-0.004 \\
(-1.19)\end{array}$ & & $\begin{array}{r}-0.008^{*} \\
(-1.73)\end{array}$ & $\begin{array}{r}-0.009^{* *} \\
(-2.01) \\
-0.005 \\
(-1.54)\end{array}$ & & & & \\
\hline earnings announcement & $\begin{array}{l}-0.001 \\
(-0.06)\end{array}$ & $\begin{array}{l}-0.001 \\
(-0.13)\end{array}$ & $\begin{array}{l}-0.001 \\
(-0.09)\end{array}$ & $\begin{array}{l}-0.014 \\
(-1.08)\end{array}$ & $\begin{array}{l}-0.014 \\
(-1.11)\end{array}$ & $\begin{array}{r}-0.014 \\
(1.10)\end{array}$ & $\begin{array}{l}-0.001 \\
(-0.10)\end{array}$ & $\begin{array}{l}-0.001 \\
(-0.08)\end{array}$ & $\begin{array}{l}-0.013 \\
(-0.95)\end{array}$ & $\begin{array}{l}-0.013 \\
(-0.94)\end{array}$ \\
\hline earnchg & & & & $\begin{array}{r}-0.014 * * \\
(-2.41)\end{array}$ & $\begin{array}{r}-0.013^{* *} \\
(-2.29)\end{array}$ & $\begin{array}{r}-0.013^{* *} \\
(-2.45)\end{array}$ & & & $\begin{array}{r}-0.013^{* *} \\
(-2.16)\end{array}$ & $\begin{array}{r}-0.012^{* *} \\
(-2.20)\end{array}$ \\
\hline size & $\begin{array}{r}0.002 * \\
(1.83)\end{array}$ & $\begin{array}{l}0.001 \\
(1.19)\end{array}$ & $\begin{array}{r}0.002 \\
(1.23)\end{array}$ & $\begin{array}{r}0.002 * * \\
(1.98)\end{array}$ & $\begin{array}{l}0.001 \\
(1.26)\end{array}$ & $\begin{array}{l}0.002 \\
(1.37)\end{array}$ & $\begin{array}{r}0.002 * * \\
(-2.20)\end{array}$ & $\begin{array}{r}0.002 \\
(1.27)\end{array}$ & $\begin{array}{r}0.002 * * \\
(2.05)\end{array}$ & $\begin{array}{l}0.002 \\
(1.26)\end{array}$ \\
\hline profitability & $\begin{array}{l}0.019 \\
(1.64)\end{array}$ & $\begin{array}{r}0.019^{*} \\
(1.70)\end{array}$ & $\begin{array}{l}0.019 \\
(1.65)\end{array}$ & $\begin{array}{l}0.018 \\
(1.66)\end{array}$ & $\begin{array}{r}0.019^{* *} \\
(1.72)\end{array}$ & $\begin{array}{r}0.018^{*} \\
(1.66)\end{array}$ & $\begin{array}{r}0.013 \\
(1.12)\end{array}$ & $\begin{array}{l}0.013 \\
(1.12)\end{array}$ & $\begin{array}{r}0.012 \\
(0.99)\end{array}$ & $\begin{array}{l}0.012 \\
(0.94)\end{array}$ \\
\hline growth & $\begin{array}{r}0.004 * * \\
(2.40)\end{array}$ & $\begin{array}{r}0.004 * * * \\
(2.74)\end{array}$ & $\begin{array}{r}0.004 * * * \\
(2.91)\end{array}$ & $\begin{array}{r}0.004^{* * * *} \\
(2.64)\end{array}$ & $\begin{array}{r}0.004 * * * \\
(3.00)\end{array}$ & $\begin{array}{r}0.004^{* * * *} \\
(3.15)\end{array}$ & $\begin{array}{r}0.004^{* *} \\
(2.30)\end{array}$ & $\begin{array}{l}0.004 * * \\
(2.34)\end{array}$ & $\begin{array}{r}0.004 * * * \\
(2.63)\end{array}$ & $\begin{array}{r}0.004 * * * \\
(2.67)\end{array}$ \\
\hline leverage & $\begin{array}{r}0.003 \\
(0.26)\end{array}$ & $\begin{array}{l}0.007 \\
(0.75)\end{array}$ & $\begin{array}{l}0.005 \\
(0.56)\end{array}$ & $\begin{array}{l}0.001 \\
(0.08)\end{array}$ & $\begin{array}{l}0.005 \\
(0.60)\end{array}$ & $\begin{array}{l}0.003 \\
(0.33)\end{array}$ & $\begin{array}{r}0.005 \\
(0.42)\end{array}$ & $\begin{array}{l}0.007 \\
(0.57)\end{array}$ & $\begin{array}{l}0.003 \\
(0.31)\end{array}$ & $\begin{array}{r}0.005 \\
(0.44)\end{array}$ \\
\hline investment & $\begin{array}{l}0.059 \\
(1.56)\end{array}$ & $\begin{array}{l}0.061 \\
(1.44)\end{array}$ & $\begin{array}{l}0.060 \\
(1.52)\end{array}$ & $\begin{array}{r}0.071^{* *} \\
(2.07)\end{array}$ & $\begin{array}{r}0.072 * \\
(1.84)\end{array}$ & $\begin{array}{r}0.071^{* *} \\
(1.99)\end{array}$ & $\begin{array}{l}0.027 \\
(0.43)\end{array}$ & $\begin{array}{l}0.018 \\
(0.24)\end{array}$ & $\begin{array}{l}0.040 \\
(0.69)\end{array}$ & $\begin{array}{r}0.033 \\
(0.46)\end{array}$ \\
\hline imr & $\begin{array}{l}-0.005 \\
(-0.30)\end{array}$ & $\begin{array}{l}-0.009 \\
(-0.62)\end{array}$ & $\begin{array}{l}-0.007 \\
(-0.45)\end{array}$ & $\begin{array}{l}-0.003 \\
(-0.19)\end{array}$ & $\begin{array}{l}-0.008 \\
(-0.52)\end{array}$ & $\begin{array}{r}-0.005 \\
(-0.30)\end{array}$ & & $\begin{array}{l}-0.007 \\
(-0.47)\end{array}$ & & $\begin{array}{l}-0.005 \\
(-0.39)\end{array}$ \\
\hline Adj. $R^{2}$ & $2.22 \%$ & $2.29 \%$ & $1.99 \%$ & $3.21 \%$ & $3.10 \%$ & $2.90 \%$ & $0.97 \%$ & $0.61 \%$ & $1.75 \%$ & $1.36 \%$ \\
\hline No. of obs. & 231 & 231 & 231 & 231 & 231 & 231 & 225 & 225 & 225 & 225 \\
\hline
\end{tabular}

Panel A shows the results of a logistic regression of Wells disclosers $(=1)$ and AAER firms that did not disclose a Wells notice $(=0)$ on variables to explain a company's decision to disclose a Wells notice. We use the likelihood of a Wells disclosure by firms that actually made a Wells disclosure in the second-stage regression (Panel B) to construct the inverse Mills ratio (imr) as a test of selection bias. Panel B summarizes the second-stage regressions of market-adjusted excess stock return for first-time Wells disclosers for days -1 to 1 on litigation and other determinants of excess return. The litigation variable definitions for regressions 1-6 are: litigation $=1$ if the firms are subject to subsequent litigation, such as an AAER or shareholder litigation, 0 otherwise; timely litigation $=1$ if litigation occurs within 12 months of Wells notice disclosure, 0 otherwise; delayed litigation $=1$ if litigation occurs after 12 months to 5 years of Wells notice disclosure, 0 otherwise. The definition of litigation for regressions 7-10 = 1 if ex-ante litigation risk per Eq. (2) of Kim and Skinner (2012) is greater than median, otherwise 0. See Appendix A for variable definitions. Except as stated otherwise, all variables relate to the fiscal year prior to the year of Wells disclosure. $* * *=$ significant at $<.001, * *=$ significant at $<.01$, and $*=$ significant at $<.05$ using a two-tailed test. All $\mathrm{t}$-values are calculated using standard errors clustered by company and year.

First, Panel A shows the results of the disclosure model used to construct the imr variable in Eq. (1). The following variables significantly explain a company's decision to disclose a Wells notice. Wells firms are larger in market value (log mktcap), have fewer shareholders (log cshrs), trade more often (log tradvol), have lower return on assets volatility (roavolat), belong to certain litigation-prone industries (industry), and are less leveraged (leverage). Interestingly, based on Kim and Skinner (2012), while some of these variables support the view that Wells disclosers are also lower litigation risk firms (e.g., leverage, roavolat, industry), others do not (e.g., log mktcap, tradevol). In other words, not all Wells disclosers have lower litigation risk attributes, a result that is also consistent with the point we made earlier, namely, that firms that disclose bad news early do not necessarily experience higher litigation cost or likelihood (Skinner, 1994, Field et al., 2005).

Panel B shows the results of regressing the three-day excess return around a Wells disclosure on the litigation variable, several control variables, and imr. The first six regressions define the litigation variable as litigation, timely litigation, or delayed litigation. First, all six of the regressions indicate significantly negative coefficients for litigation or timely litigation, where timely litigation occurs within 12 months of Wells disclosure date. For example, litigation in regression 1 has a significantly negative coefficient $\left(\alpha_{2}=-0.007, \mathrm{t}\right.$ val. $\left.=-2.74\right)$. Regression 3 shows a significantly negatively coefficient for timely litigation $\left(\alpha_{2}=-0.009, \mathrm{t}\right.$ val. $\left.=-2.12\right)$ that exceeds negatively the coefficient for delayed litigation, which is not significant $\left(\alpha_{2}=-0.004, \mathrm{t}=-1.19\right)$. In regressions 4 to 6 , we add an earnings surprise variable and repeat the analysis as a check of whether such effects might interact with the litigation coefficients. These regressions show results similar to regressions 1 to 3 for litigation and timely litigation, and so earnings announcement factors do not influence our main results. In addition, the coefficient for imr is not significantly different from zero, suggesting that an analysis of Wells disclosers and Wells non-disclosers does not 
bias our results, in particular, the explanatory role of litigation. (Note 14) We also repeat the analysis excluding observations (32 out of 231) that have earnings announcements on Wells disclosure days -1 to 1 . Untabulated analysis shows that these results are similar to regressions 1 to 6 , although slightly less significant, which confirms further that earnings news in the event window does not appreciably change our results.

We then repeat the analysis using ex-ante litigation risk as the litigation variable. Regressions 7 to 10 summarize the results. The coefficient for litigation while negative is insignificant. In other words, this variable offers no additional explanatory power to the model, consistent with the view that investors do not condition their response to a Wells notice on contemporaneous information about litigation risk, presumably because that information is already in prices based on an earlier analysis. The differences between regressions 1-6 and 7-10 are clear. When we define litigation with respect to subsequent litigation the results are significant, but when we define litigation with respect to public information they are not. We also estimated regressions 7-10 with litigation defined in terms of the occurrence of litigation in the prior five years. The $\alpha_{2}$ coefficient for prior litigation was similarly insignificant. We conclude from this analysis that investors extract additional information from a Wells disclosure and that this information relates to litigation risk. Consistent with Table 2, the coefficients increase negatively from ex-ante litigation $\left(\alpha_{2}=-0.005\right.$ to -0.006 , not significant) (regressions 7-10), to subsequent litigation $\left(\alpha_{2}=-0.007\right.$, significant) (regressions 1 and 4), to timely litigation ( $\alpha_{2}=-0.008$ to -0.009 , significant) (regressions $2,3,5$, and 6). In short, these results support $\mathrm{H2}$ - that investors' response varies negatively with Wells notice related litigation risk.

Finally, we make two further observations. First, we find that the addition of the control variables has little impact on the results, except for growth, which is positive and significant, consistent with the view that lower growth stocks reflect a more negative response. Second, we find that the combined effects of $\alpha_{1}$ and $\alpha_{2}$ for timely litigation in regressions 2 (or 5) and 3 (or 6) of $-0.038(-0.039$ ), and $-0.045(-0.050)$, respectively, compare well with the univariate results in Panel $\mathrm{C}$ of Table 2. The latter indicate a cumulative mean response over days -1 to 1 of -4.50 percent for first-time 8-K disclosers with timely litigation.

\subsection{Wells Notice Receipt}

Some firms report the receipt of a Wells notice promptly in an 8-K, whereas others wait until a subsequent 10-Q or $10-\mathrm{K}$ to report such receipt, and some make no disclosure at all. Through these subsequent disclosures, we are able to identify 129 cases where a company discloses the receipt day of a Wells notice and 39 cases that mention the month of receipt only. Another 41 disclosure firms chose not to state the receipt date. Among the 129 filings, 79 report the receipt date in a first-time $8-\mathrm{K}$ disclosure, and 34 and 16 of them report the receipt date in a later 10-Q and 10-K, respectively (Table 4, Panel A). The filing lag between receipt and disclosure date has a mean of 28 days and a median of 7 days, although the lag is considerably reduced for 8-Ks (mean of 7 days and a median of 4 days). Panel B of Table 4 summarizes our tests of investor response around receipt date. Our expectation is that investors will not respond on receipt date since there is no clear obligation for immediate disclosure upon receipt of the letter. This is what we find. Panel B of Table 4 shows the results for three groups with an identifiable receipt date: all Wells receipt dates, $8-\mathrm{K}$ receipt dates, and $10-\mathrm{K} / 10-\mathrm{Q}$ receipt dates. In all cases, we observe no significant investor reaction on receipt date. This suggests that the receipt of a Wells notice remains non-public information around that date.

Table 4. Investors' response around Wells notice receipt

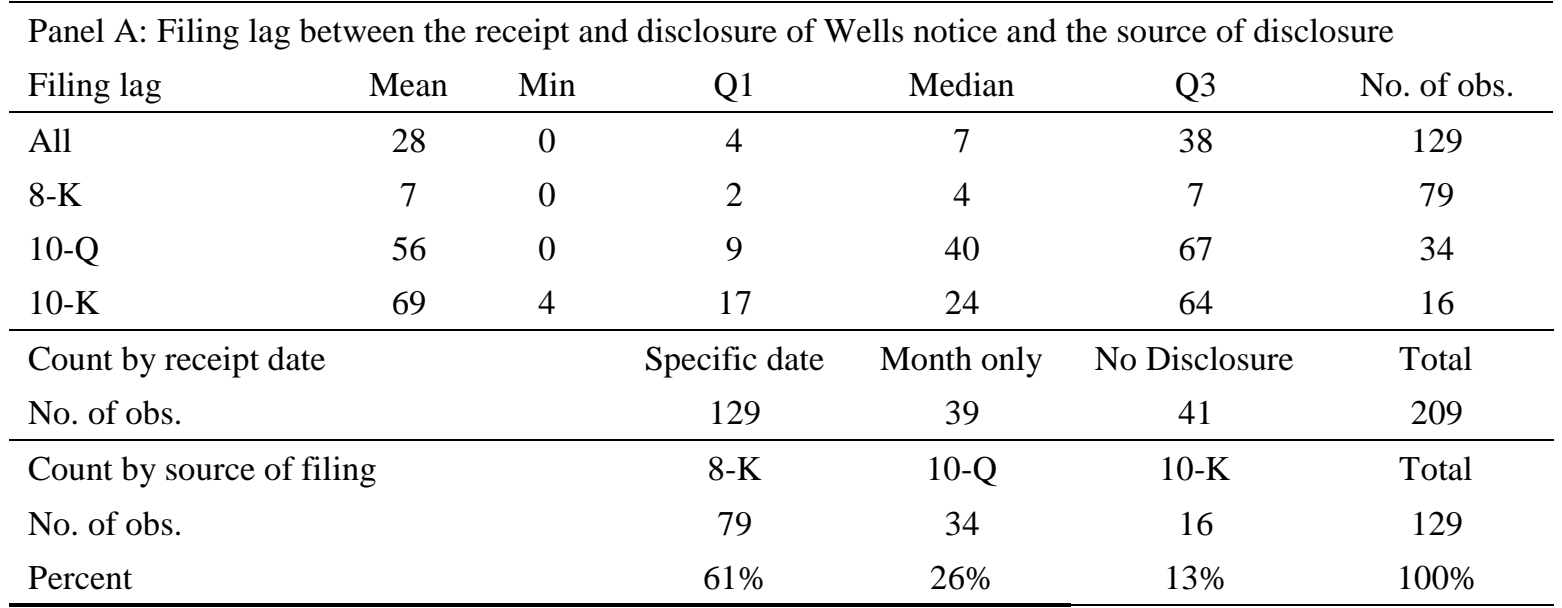




\begin{tabular}{|c|c|c|c|c|c|c|}
\hline \multirow[b]{2}{*}{ Trading day } & \multicolumn{2}{|c|}{ All } & \multicolumn{2}{|c|}{$8-\mathrm{K}$} & \multicolumn{2}{|c|}{$10-\mathrm{K} \& 10-\mathrm{Q}$} \\
\hline & $\mathrm{N}$ & Mean & $\mathrm{N}$ & Mean & $\mathrm{N}$ & Mean \\
\hline-2 & 62 & -0.002 & 38 & 0.001 & 24 & -0.005 \\
\hline-1 & 62 & 0.013 & 38 & 0.013 & 24 & 0.013 \\
\hline 0 & 62 & -0.003 & 38 & 0.007 & 24 & -0.018 \\
\hline 1 & 62 & -0.002 & 38 & -0.008 & 24 & 0.006 \\
\hline 2 & 62 & -0.011 & 38 & -0.006 & 24 & -0.02 \\
\hline Sum (-1 to 1$)$ & & 0.008 & & 0.012 & & 0.002 \\
\hline t-val. (2-tailed) vs. 0 & & 0.888 & $\mathrm{~ns}$ & 0.821 & ns & 0.388 \\
\hline Sum (-2 to 2$)$ & & -0.005 & & 0.007 & & -0.023 \\
\hline t-val. (2-tailed) vs. 0 & & -0.558 & ns & 0.127 & ns & -1.092 \\
\hline
\end{tabular}

Panel A shows the filing lag between the receipt and disclosure of Wells notice, and the sample composition by the extent of receipt date disclosure, and by the source of disclosure. Panel B presents the mean market-adjusted excess return over event days -2 to 2 around the Wells receipt day. Market-adjusted excess stock return $=$ the return on stock i for day $t$ minus the return on the value-weighted index of stocks in the CRSP database, where $t$ is relative to Wells receipt date; Sum (-1 to 1$)=$ the sum of the man excess return from day -1 to 1 ; Sum $(-2$ to 2$)=$ the sum of the man excess return from day -2 to 2 ; and Signif. = significance that the mean market-adjusted excess return is different from zero. $* * *=$ significant at $<.001, * *=$ significant at $<.01, *=$ significant at $<.05$, and ns=not significant using a two-tailed test.

\subsection{Adjusted Volume and Bid-ask Spread}

We test for investor reaction to a Wells disclosure based on two other response metrics in the literature: daily adjusted trading volume and bid-ask spread, where adjusted trading volume $=$ trading volume for day $t$ divided by shares outstanding at day $t$, and bid-ask spread $=\left(\right.$ quoted ask $\mathrm{t}_{\mathrm{t}}-$ quoted bid $\left.{ }_{\mathrm{t}}\right) \div\left[\left(\right.\right.$ quoted ask $\mathrm{t}_{\mathrm{t}}+$ quoted bid $\left.\left.\mathrm{d}_{\mathrm{t}}\right) / 2\right]$ for day $t$. Regarding information effects, Lee, Mucklow and Ready (1993) find that adjusted trading volume and bid-ask spread increase significantly around the day of an earnings release and drop soon thereafter. We expect to find a similar pattern for Wells disclosures.

Table 5. Daily adjusted volume around a Wells disclosure

\begin{tabular}{|c|c|c|c|c|c|c|c|}
\hline \multicolumn{8}{|c|}{ Panel A: Comparison between first-time 8-K disclosers and first-time 10-K/10-Q disclosers } \\
\hline \multirow[b]{2}{*}{ Trading day } & \multicolumn{2}{|l|}{ First-time } & \multicolumn{2}{|l|}{ First time } & \multirow[b]{2}{*}{ Diff. } & \multirow{2}{*}{$\begin{array}{l}\text { t-val. } \\
\text { Diff. }\end{array}$} & \multirow[b]{2}{*}{ Signif. } \\
\hline & $8-\mathrm{K}$ & $\mathrm{N}$ & $10-K / 10-Q$ & $\mathrm{~N}$ & & & \\
\hline-2 & 9.6218 & 80 & 15.2606 & 39 & & & \\
\hline-1 & 8.0392 & 80 & 22.5404 & 39 & & & \\
\hline 0 & 17.4012 & 80 & 14.8376 & 39 & & & \\
\hline 1 & 13.8555 & 80 & 11.9725 & 39 & & & \\
\hline 2 & 11.1066 & 80 & 10.3175 & 39 & & & \\
\hline Mean (-1 to 1$)$ & 13.0986 & & 16.4502 & & -3.3515 & 1.3653 & $\mathrm{~ns}$ \\
\hline t-val. (2-tailed) vs. sample & 2.0520 & $*$ & 2.4214 & $* *$ & & & \\
\hline Mean (-2 to 2) & 12.0049 & & 14.9857 & & -2.9808 & 1.7383 & $*$ \\
\hline t-val. (2-tailed) vs. sample & 1.8378 & $*$ & 2.6508 & $* *$ & & & \\
\hline Mean (-2 to 30$)$ & 9.9143 & & 13.8134 & & -3.8991 & 4.3934 & $* * *$ \\
\hline t-val. (2-tailed) vs. sample & -1.3105 & ns & 3.0684 & $* *$ & & & \\
\hline
\end{tabular}




\begin{tabular}{|c|c|c|c|c|c|c|c|}
\hline \multicolumn{8}{|c|}{ Panel B: Comparison between first-time 8-K disclosers with high versus low ex-ante litigation risk } \\
\hline Trading day & $\begin{array}{r}\text { First-time } 8-\mathrm{K} \\
\text { with high ex-ante } \\
\text { litigation risk }\end{array}$ & $\mathrm{N}$ & $\begin{array}{r}\text { First-time } 8-\mathrm{K} \\
\text { with low ex-ante } \\
\text { litigation risk }\end{array}$ & $\mathrm{N}$ & Diff. & $\begin{array}{c}\text { t-val. } \\
\text { Diff. }\end{array}$ & Signif. \\
\hline-2 & 12.7912 & 37 & 8.0279 & 38 & & & \\
\hline-1 & 12.7912 & 37 & 6.6254 & 38 & & & \\
\hline 0 & 25.3841 & 37 & 10.5536 & 38 & & & \\
\hline 1 & 18.6044 & 37 & 10.9813 & 38 & & & \\
\hline 2 & 13.8755 & 37 & 8.7917 & 38 & & & \\
\hline Mean (-1 to 1$)$ & 18.9265 & & 9.3867 & & 9.5398 & 3.0705 & $* *$ \\
\hline t-val. (2-tailed) vs. sample & 2.8526 & $* *$ & -1.0573 & ns & & & \\
\hline Mean (-2 to 2$)$ & 16.6893 & & 8.9960 & & 7.6933 & 3.7337 & $* * *$ \\
\hline t-val. (2-tailed) vs. sample & 3.2171 & $* * *$ & -1.9742 & $*$ & & & \\
\hline Mean (-2 to 30$)$ & 12.9924 & & 7.7774 & & 5.2150 & 9.4839 & $* * *$ \\
\hline t-val. (2-tailed) vs. sample & 5.3778 & $* * *$ & -9.6915 & $* * *$ & & & \\
\hline
\end{tabular}

Panel C: Comparison between first-time 8-K disclosers with timely litigation and first-time 8-K disclosers with delayed litigation

\begin{tabular}{|c|c|c|c|c|c|c|c|}
\hline Trading day & $\begin{array}{r}\text { First-time } 8-K \\
\text { with timely } \\
\text { litigation }\end{array}$ & $\mathrm{N}$ & $\begin{array}{r}\text { First-time } 8-\mathrm{K} \\
\text { with delayed } \\
\text { litigation }\end{array}$ & $\mathrm{N}$ & Diff. & $\begin{array}{l}\text { t-val. } \\
\text { Diff. }\end{array}$ & Signif. \\
\hline-2 & 6.9828 & 23 & 5.7981 & 19 & & & \\
\hline-1 & 5.9525 & 23 & 6.6395 & 19 & & & \\
\hline 0 & 11.0360 & 23 & 22.2497 & 19 & & & \\
\hline 1 & 9.3385 & 23 & 14.9579 & 19 & & & \\
\hline 2 & 8.3474 & 22 & 8.5005 & 19 & & & \\
\hline Mean $(-1$ to 1$)$ & 8.7757 & & 14.6157 & & -5.8400 & -1.4641 & ns \\
\hline t-val. (2-tailed) vs. sample & -1.3919 & $\mathrm{~ns}$ & 1.0146 & ns & & & \\
\hline $\operatorname{Mean}(-2$ to 2$)$ & 8.3314 & & 11.6291 & & -3.2977 & -1.3234 & ns \\
\hline t-val. (2-tailed) vs. sample & -2.5296 & $* *$ & 0.5145 & ns & & & \\
\hline Mean (-2 to 30$)$ & 8.0293 & & 8.8424 & & -0.8130 & -1.1509 & ns \\
\hline t-val. (2-tailed) vs. sample & -6.2342 & $* * *$ & -2.1909 & $*$ & & & \\
\hline
\end{tabular}

This table shows the mean adjusted volume over event days -2 to 2 . Day 0 refers to the Wells disclosure date. Panel A reports all first-time Wells disclosures partitioned on the source of disclosure. Panel B reports first-time 8-K Wells disclosures partitioned on the presence of high ex-ante litigation and low ex-ante litigation. Panel $\mathrm{C}$ reports first-time 8 -K Wells disclosures partitioned on timely and delayed litigation. Daily adjusted volume $=$ trading volume for day $t$ divided by common shares outstanding at day $t$; mean $(-1$ to 1$)=$ the average of daily adjusted volume from day -1 to 1 ; mean $(-2$ to 2$)=$ the average of daily adjusted volume from day -2 to 2 ; mean $(-2$ to 30$)=$ the average of daily adjusted volume from day -2 to $30 ; * * *=$ significant at $<.001, * *=$ significant at $<.01, *=$ significant at $<.05$, and ns=not significant using a two-tailed test = significance level of a two-tailed t test that the mean adjusted volume differs from the mean adjusted volume of the entire sample; and Signif. in the last column = significance level of a two-tailed t test that mean adjusted volume differ between the two groups.

Each panel of Table 5 shows the mean adjusted volume for each of days -2 to 2 . First, Panel A shows that adjusted trading volume increases significantly over days -1 to 1 and -2 to 2 for first-time $8-\mathrm{K}$ and $10-\mathrm{K} / 10-\mathrm{Q}$ disclosers relative to the sample mean, calculated as mean daily adjusted volume over days -20 to 20 , excluding the event days. Consistent with our earlier results, we observe that the volume increase on day 0 is most pronounced for the 8 -K 
sample. Panels B and C show similar volume effects for first-time 8-K disclosers with high and low ex-ante litigation (Panel B) and with timely and delayed litigation (Panel C). On the other hand, the absolute adjusted volume levels are higher for first-time $10-\mathrm{K} / 10-\mathrm{Q}$ disclosers, but this likely reflects investors' more widespread and anticipated interest in the release of a $10-\mathrm{K}$ or $10-\mathrm{Q}$ report versus an $8-\mathrm{K}$. Overall, these results comport with Table 2, in that we observe a significant volume reaction on the same days as we observe a significant negative price reaction, and the volume and price effects are most pronounced for first-time 8-K disclosures.

Table 6 analyzes bid-ask spread in a similar way and shows, consistent with information flow, that the spreads widen over days -2 to 1 and diminish thereafter. For example, for first-time 8-K disclosers (Panel A), the mean spread increases from 0.42 (day -2) to 0.63 (day -1) and then decreases to 0.44 (day 2). The spreads are also significantly higher over days -1 to 1 or -2 to 2 relative to the average bid-ask spread for the sample (based on days -20 to 20 excluding the event days). Assuming that quoted spread reflects the probability that some traders have superior information (Kim \& Verrecchia, 1991), spreads should increase prior to announcement as specialists and dealers anticipate increased information asymmetry, and this is what we find. (Note 15) We also examine different definitions of bid-ask spread for day $t$, for example, raw spread (no deflation), spread deflated by day $t$ trading volume, and spread deflated by day $t-1$ quoted ask plus quoted bid, with no change in the results.

Table 6. Daily bid-ask spread around a Wells disclosure

\begin{tabular}{|c|c|c|c|c|c|c|c|}
\hline \multicolumn{8}{|c|}{ Panel A: Comparison between first-time $8-\mathrm{K}$ disclosers and first-time $10-\mathrm{K} / 10-\mathrm{Q}$ disclosers } \\
\hline \multirow[b]{2}{*}{ Trading day } & \multicolumn{2}{|l|}{ First-time } & \multicolumn{2}{|l|}{ First time } & \multicolumn{3}{|c|}{ t-val. } \\
\hline & $8-K$ & $\mathrm{~N}$ & $10-K / 10-Q$ & $\mathrm{~N}$ & Diff. & Diff. & Signif. \\
\hline-2 & 0.0421 & 80 & 0.0449 & 39 & & & \\
\hline-1 & 0.0635 & 80 & 0.0534 & 39 & & & \\
\hline 0 & 0.0494 & 80 & 0.0424 & 39 & & & \\
\hline 1 & 0.0538 & 80 & 0.0411 & 39 & & & \\
\hline 2 & 0.0438 & 80 & 0.0374 & 39 & & & \\
\hline Mean $(-1$ to 1$)$ & 0.0556 & & 0.0456 & & 0.0099 & 0.7986 & ns \\
\hline t-val. (2-tailed) vs. sample & 1.8180 & $*$ & 1.3273 & ns & & & \\
\hline Mean (-2 to 2$)$ & 0.0505 & & 0.0438 & & 0.0067 & 0.8475 & ns \\
\hline t-val. (2-tailed) vs. sample & 1.9647 & $*$ & 1.0665 & ns & & & \\
\hline Mean (-2 to 30$)$ & 0.0431 & & 0.0382 & & 0.0049 & 2.6470 & $* *$ \\
\hline t-val. (2-tailed) vs. sample & 2.2108 & $*$ & -2.2009 & * & & & \\
\hline \multicolumn{8}{|c|}{ Panel B: Comparison between first-time 8-K disclosers with high versus low ex-ante litigation risk } \\
\hline Trading day & $\begin{array}{r}\text { First-time } 8-\mathrm{K} \\
\text { with high ex-ante } \\
\text { litigation risk }\end{array}$ & $\mathrm{N}$ & $\begin{array}{r}\text { First-time } 8-\mathrm{K} \\
\text { with low ex-ante } \\
\text { litigation risk }\end{array}$ & $\mathrm{N}$ & Diff. & $\begin{array}{l}\text { t-val. } \\
\text { Diff. }\end{array}$ & Signif. \\
\hline-2 & 0.0400 & 37 & 0.0399 & 38 & & & \\
\hline-1 & 0.0377 & 37 & 0.0419 & 38 & & & \\
\hline 0 & 0.0491 & 37 & 0.0522 & 38 & & & \\
\hline 1 & 0.0472 & 37 & 0.0570 & 38 & & & \\
\hline 2 & 0.0411 & 37 & 0.0477 & 38 & & & \\
\hline Mean (-1 to 1$)$ & 0.0447 & & 0.0504 & & -0.0057 & -1.0118 & ns \\
\hline t-val. (2-tailed) vs. sample & 1.0953 & ns & 2.4683 & $* *$ & & & \\
\hline Mean (-2 to 2$)$ & 0.0430 & & 0.0477 & & -0.0047 & -1.1463 & ns \\
\hline t-val. (2-tailed) vs. sample & 0.9304 & ns & 2.4624 & $* *$ & & & \\
\hline Mean (-2 to 30$)$ & 0.0410 & & 0.0428 & & -0.0018 & -1.1371 & ns \\
\hline t-val. (2-tailed) vs. sample & 0.5141 & ns & 2.0818 & $*$ & & & \\
\hline
\end{tabular}


Panel C: Comparison between first-time 8-K disclosers with timely litigation and first-time 8-K disclosers with delayed litigation

\begin{tabular}{|c|c|c|c|c|c|c|c|}
\hline Trading day & $\begin{array}{r}\text { First-time } 8-\mathrm{K} \\
\text { with timely } \\
\text { litigation }\end{array}$ & $\mathrm{N}$ & $\begin{array}{r}\text { First-time } 8-\mathrm{K} \\
\text { with delayed } \\
\text { litigation }\end{array}$ & $\mathrm{N}$ & Diff. & $\begin{array}{l}\text { t-val. } \\
\text { Diff. }\end{array}$ & Signif. \\
\hline-2 & 0.0389 & 23 & 0.0259 & 19 & & & \\
\hline-1 & 0.0413 & 23 & 0.0207 & 19 & & & \\
\hline 0 & 0.0512 & 23 & 0.0302 & 19 & & & \\
\hline 1 & 0.0535 & 23 & 0.0351 & 19 & & & \\
\hline 2 & 0.0471 & 22 & 0.0245 & 19 & & & \\
\hline Mean $(-1$ to 1$)$ & 0.0487 & & 0.0287 & & 0.0200 & 3.2882 & $* * *$ \\
\hline t-val. (2-tailed) vs. sample & 1.7988 & $*$ & -3.1499 & $* * *$ & & & \\
\hline $\operatorname{Mean}(-2$ to 2$)$ & 0.0464 & & 0.0273 & & 0.0191 & 4.3907 & $* * *$ \\
\hline t-val. (2-tailed) vs. sample & 1.8624 & $*$ & -4.6414 & $* * *$ & & & \\
\hline Mean (-2 to 30$)$ & 0.0410 & & 0.0261 & & 0.0148 & 9.2919 & $* * *$ \\
\hline t-val. (2-tailed) vs. sample & 0.4918 & ns & -13.3794 & $* * *$ & & & \\
\hline
\end{tabular}

This table presents mean daily bid-ask spread over event days -2 to 2 . Day 0 refers to the Wells disclosure date. Panel A reports all first-time Wells disclosures partitioned on the source of disclosure. Panel B reports first-time 8-K Wells disclosures partitioned on the presence of subsequent litigation (AAER or shareholder action within 5 years). Panel C reports first-time $8-\mathrm{K}$ Wells disclosures partitioned on timely and delayed litigation. Daily bid-ask spread = $(($ ask-bid $) \div($ ask + bid $) / 2)$ for disclosure day $t$; mean $(-1$ to 1$)=$ the average of daily bid-ask spread from day -1 to 1 ; mean $(-2$ to 2$)=$ the average of daily bid-ask spread from day -2 to 2 ; mean $(-2$ to 30$)=$ the average of daily bid-ask spread from day -2 to $30 ; * * *=$ significant at $<.001, * *=$ significant at $<.01, *=$ significant at $<.05$, and ns=not significant $=$ significance level of a two-tailed $t$ test that mean bid-ask spread differs from the mean bid-ask spread of the sample; and Signif. in the last column= significance level of a two-tailed $t$ test that mean bid-ask spread differs between the two groups.

\subsection{Summary}

We find that investors respond negatively to first-time Wells disclosures in SEC filings, more negatively to first-time Wells disclosures with subsequent litigation, and even more negatively to first-time Wells disclosures with timely litigation. These results are driven mainly by first-time 8-Ks, which enable a cleaner test of market response, as 8-Ks are less influenced by other news than 10-K/10-Qs (Tables 2, 3, and 4). Higher adjusted trading volume and wider bid-ask spreads around the Wells disclosure date also support the hypothesis that first-time Wells disclosers conditional on subsequent litigation and timely litigation signal adverse news to investors (Tables 5 and 6). These results also support our risk hypotheses, namely, that stock prices decrease around Wells disclosure dates more for first-time 8-K Wells disclosers than for the other Wells discloser groups, and this response varies negatively in litigation risk. Our results also offer evidence that prior studies of the price effects of antecedent events such as securities litigation and financial restatements may have understated the impact of those events by not controlling for Wells notices.

\subsection{News Prominence}

While we predict and find that investors' response to a Wells notice varies negatively in litigation risk, another explanation could relate to the prominence of the disclosure (Files, Swanson, \& Tse, 2009), whereby the more prominent first-time $8-\mathrm{K}$ disclosures elicit a more negative price response. To implement this test, we split the first-time 8-K sample into high and low prominence groups, where high prominence refers to a first-time 8-K with a press release that mentions the Wells notice or a first-time 8-K without a press release but where the Wells disclosure is the sole item of the $8-\mathrm{K}(\mathrm{N}=59)$. Otherwise, we assign a first-time $8-\mathrm{K}$ to the non-prominent group $(\mathrm{N}=21)$. We then conduct the same tests as in Table 2. Untabulated results show a significantly negative mean three-day excess return over days -1 to 1 for both the high prominence and low prominence disclosure groups, and the three-day excess returns do not differ significantly from one another. As such, an alternative hypothesis - that our results are driven mainly by high prominence disclosures - does not offer a likely explanation. 


\section{Conclusions}

This study adds to the literature by shedding new light on investors' response to a Wells notice and is intended to help firms make informed and possibly more ethical decisions about an important disclosure item and to inform investors of its consequences. We find that stock prices fall, and trading volume and bid-ask spread rise significantly in the three days around a first-time Wells disclosure. For first-time 8-K disclosures that involve SEC or shareholder litigation within 12 months after disclosure date, we observe a three-day cumulative excess return over days -1 to 1 of approximately -4.5 percent. This return exceeds negatively the three-day excess return of -2.52 percent for Wells disclosures with high predicted litigation risk based on contemporaneous public information. This implies that Wells notices reveal unique information for investors about litigation risk not reflected in contemporaneous public information. We also observe no significant price response for firms that may wait to disclose their first-time Wells disclosure in a $10-\mathrm{K}$ or $10-\mathrm{Q}$. This finding raises the possibility that some managers choose the potentially less ethical option of disclosing on a delayed basis in a 10-K or 10-Q to avoid or mute the initial 8-K effect.

To strengthen our results, we employ a regression approach that tests for a relation between three-day excess return around Wells disclosure date and litigation risk, with controls for the other determinants of excess stock return. We also control for the possible selection bias from analyzing Wells disclosers only rather than all Wells notice recipients. This analysis also shows a negative stock reaction around Wells disclosure days -1 to 1 that associates negatively with litigation risk based on timely litigation but has no association with predicted litigation risk based on contemporaneous public information. These regression results also imply that Wells disclosures reveal unique information about litigation risk not reflected in contemporaneous public information.

On the other hand, for firms that report the Wells receipt date, we observe no market reaction over receipt days -1 to 1. This suggests that the initial receipt remains confidential to outside investors. However, this result is based on a limited sample of firms that, in most cases, voluntarily disclosed the receipt date. A larger sample of all Wells letters sent by the SEC to firms (and Wells submission letters sent to the SEC in response) over an extended period would enable a more determinative finding. In this regard, a Freedom of Information Act (FOIA) request to the SEC proved unsuccessful, in that while we received a complete listing of Wells notices for 2011-2012 from the SEC, an insufficient number related to firms with data for the statistical testing.

From the standpoint of disclosure policy, our results imply that investors consider a Wells notice as a price-sensitive event. Some firms treat a Wells notice in this way and disclose its receipt promptly in an 8-K. However, others do not, perhaps because current SEC policy does not define a Wells notice as a pending legal proceeding requiring disclosure under Regulation S-K, Item 103, or perhaps because managers perceive (and our results show) that a possible later disclosure in a $10-\mathrm{K}$ or $10-\mathrm{Q}$ might have a more muted stock price effect given the passage of time. Our results also imply that prior studies of accounting litigation and financial restatements may have underestimated the overall impact those events by not considering the precursory effects of Wells notices.

\section{Acknowledgements}

We thank Joseph A. Grundfest (Stanford Law School), Zining Li (Cox School of Business, Southern Methodist University, the journal editor, and two reviewers for their useful comments.

\section{References}

Anderson, A., \& Dyl, E. (2005). Market structure and trading volume. The Journal of Financial Research, 28(1), 115-131. http://dx.doi.org/10.1111/j.1475-6803.2005.00117.x

Astarita, M. (2010). The Wells notice in SEC and NASD investigations. http://www.seclaw.com/docs/wellsnotice.htm

Atkins, P., \& Bondi, B. (2008). Evaluating the mission: A critical review of the history and evolution of the SEC enforcement program. Fordham Journal of Corporate and Financial Law, 13(3), 367-417.

Bai, L., Cox, J., \& Thomas, R. (2010). Lying and getting caught: An empirical study of the effect of securities class action settlements on targeted firms. University of Pennsylvania Law Review, 158(7), 1877-1914. http://dx.doi.org/10.2139/ssrn.1574447

Burks, J. (2010). Disciplinary measures in response to restatements after Sarbanes-Oxley. Journal of Accounting and Public Policy, 29(3), 195-225. http://dx.doi.org/10.1016/j.jaccpubpol.2010.03.002

Cao, Z., Leng, F., Feroz, E., \& Davalos, S. (2015). Corporate governance and default risk of firms cited in the SEC's Accounting and Auditing Enforcement Releases. Review of Quantitative Finance and Accounting, 44(1), 113-138. http://dx.doi.org/10.1007/s11156-013-0401-9 
Carhart, M. (1997). On persistence in mutual fund performance. The Journal of Finance, 52(1), 57-82. http://dx.doi.org/10.1111/j.1540-6261.1997.tb03808.x

Correia, M. M. (2014). Political connections and SEC enforcement. Journal of Accounting and Economics, 57(2-3), 241-262. http://dx.doi.org/10.1016/j.jacceco.2014.04.004

Dechow, P., Sloan, R., \& Sweeney, A. (1996). Causes and consequences of earnings manipulation: An analysis of firms subject to enforcement actions by the SEC. Contemporary Accounting Research, 13(1), 1-36. http://dx.doi.org/10.1111/j.1911-3846.1996.tb00489.x

Donker, H., Poff, D., \& Zahir, S. (2008). Corporate values, codes of ethics, and firm performance: A look at the Canadian context. Journal of Business Ethics, 82(3), 527-537. http://dx.doi.org/10.1007/s10551-007-9579-x

Ettredge, M., Scholz, S., Smith, K., \& Sun, L. (2010). How do restatements begin? Evidence of earnings management preceding restated financial reports. Journal of Business Finance and Accounting, 37(3), 322-355. http://dx.doi.org/10.1111/j.1468-5957.2010.02199.x

Feroz, E., Park, K., \& Pastena, V. (1991). The financial and market effects of the SEC's accounting and auditing enforcement releases. Journal of Accounting Research, 29 (Supplement), $107-142$. http://dx.doi.org/10.2307/2491006

Field, L., Lowry, M., \& Shu, S. (2005). Does disclosure deter or trigger litigation? Journal of Accounting and Economics, 39(3), 487-507. http://dx.doi.org/10.1016/j.jacceco.2005.04.004

Files, R., Swanson, E., \& Tse, S. (2009). Stealth disclosure of accounting restatements. The Accounting Review, 84(5), 1495-1520. http://dx.doi.org/10.2308/accr.2009.84.5.1495

Francis, J., Philbrick, D., \& Schipper, K. (1994). Shareholder litigation and corporate disclosures. Journal of Accounting Research, 32(2), 137-164. http://dx.doi.org/10.2307/2491279

Greenberg, H. (2008). Why do investors ignore inquiries? Wall Street Journal, April 12.

Griffin, P., Grundfest, J., \& Perino, M. (2004). Stock price response to news of securities fraud litigation: An analysis of sequential and conditional information. Abacus, 40(1), 21-48. http://dx.doi.org/10.1111/j.1467-6281.2004.00149.x

Heckman, J. (1979). Sample selection bias as a specification error. Econometrica, 47(1), 153-161. http://dx.doi.org/10.2307/1912352

Jones, C., \& Weingram, S. (1996). The determinants of 10b-5 litigation risk. Working Paper. George Washington University.

Karpoff, J., Koester, A., Lee, S., \& Martin, G. (2014). A critical analysis of databases used in financial misconduct research. Working paper, University of Washington, July 18.

Karpoff, J., Lee, S., \& Martin, G. (2008a). The cost to firms of cooking the books. Journal of Financial and Quantitative Analysis, 43(3), 581-611. http://dx.doi.org/10.1017/S0022109000004221

Karpoff, J., Lee, S., \& Martin, G. (2008b). The consequences to managers of financial misrepresentation. Journal of Financial Economics, 88(2), 193-215. http://dx.doi.org/10.1007/978-1-4614-8097-6_14

Kim, I., \& Skinner, D. (2012). Measuring securities litigation risk. Journal of Accounting and Economics, 53(1), 290-310. http://dx.doi.org/10.1016/j.jacceco.2011.09.005

Kim, O., \& Verrecchia, R. (1991). Trading volume and price reactions to public announcements. Journal of Accounting Research, 29(2), 302-321. http://dx.doi.org/10.2307/2491051

Larcker, D. F., \& Rusticus, T. O. (2010). On the use of instrumental variables in accounting research. Journal of Accounting and Economics, 49(3), 186-205. http://dx.doi.org/10.1016/j.jacceco.2009.11.004

Lee, C., Mucklow, B., \& Ready, M. (1993). Spreads, depths, and the impact of earnings information: An intraday analysis. Review of Financial Studies, 6(2), 345-374. http://dx.doi.org/10.1093/rfs/6.2.345

Leng, F., Feroz, E., Cao, Z., \& Davalos, S. (2011). The long-term performance and failure risk of firms cited in the US SEC's Accounting and Auditing Enforcement Releases. Journal of Business Finance \& Accounting, 38(7\&8), 813-841. http://dx.doi.org/10.1111/j.1468-5957.2011.02249.x

Lennox, C. S., Francis, J. R., \& Wang, Z. (2012). Selection Models in Accounting Research. The Accounting Review, 87(2), 589-616. http://dx.doi.org/10.2308/accr-10195 
Naftalis, J. (2002). Wells submissions to the SEC as offers of settlement under federal rule of evidence 408 and their Protection from third-party discovery. Columbia Law Review, 102(7), 1912-1953. http://dx.doi.org/10.2307/1123663

Nainar, S., Rai, A., \& Tartarogul, S. (2014). Market reactions to a Wells notice: An empirical analysis. International Journal of Disclosure and Governance, 11, 177-193. http://dx.doi.org/10.1057/jdg.2012.21

Nelson, C., Gilley, S., \& Trombley, G. (2009). Disclosures of SEC investigations resulting in Wells notices. Securities Litigation Journal, 19(4), 19-20.

Nourayi, M. (1994). Stock price responses to the SEC's enforcement actions. Journal of Accounting and Public Policy, 13(4), 333-347. http://dx.doi.org/10.1016/0278-4254(94)90003-5

Palmrose, Z., Richardson, V., \& Scholz, S. (2004). Determinants of market reactions to restatement announcements. Journal of Accounting and Economics, 37(1), 59-89. http://dx.doi.org/10.1016/j.jacceco.2003.06.003

Robinson, S., Robertson, J., \& Curtis, M. (2012). The effects of contextual and wrongdoing attributes on organizational employees' whistleblowing intentions following fraud. Journal of Business Ethics, 106(2), 213-227. http://dx.doi.org/10.1007/s10551-011-0990-y

Securities and Exchange Commission. (1972). Report of the Advisory Committee on Enforcement Policies and Practices, John A. Wells, Chairman, SEC: Washington DC. June 1.

Securities and Exchange Commission. (2011). SEC Enforcement Manual, Office of Chief Counsel, February 8.

Skinner, D. (1994). Why firms voluntarily disclose bad news. Journal of Accounting Research, 32(1), 38-60. http://dx.doi.org/10.2307/2491386

Skinner, D. (1997). Earnings disclosures and stockholder lawsuits. Journal of Accounting and Economics, 23(3), 249-282. http://dx.doi.org/10.1016/S0165-4101(97)00010-4

Suijs, J. (2005). Voluntary disclosure of bad news. Journal of Business Finance and Accounting, 32(7), 1423-1435. http://dx.doi.org/10.1111/j.0306-686X.2005.00634.x

Tucker, J. W. (2010). Selection bias and economic remedies in accounting and finance research. Journal of Accounting Literature, 29(Winter), 31-57.

Winer, K., \& Winer, S. (2011). Securities law techniques, Matthew Bender \& Company, a member of the Lexis-Nexis Group. 
Appendix A. Variable definitions*

\begin{tabular}{|c|c|c|}
\hline $\begin{array}{l}\text { daily adjusted volume } \\
\text { daily bid-ask spread }\end{array}$ & $\begin{array}{l}= \\
=\end{array}$ & $\begin{array}{l}\text { Trading volume ( } \mathrm{vol} \text { ) for day } t \text { divided by common shares outstanding ( } \mathrm{csho} \text { ) at day } t \text {. } \\
\text { (ask price - bid price) } \div \text { (ask price }+ \text { bid price }) / 2 \text { for day } t \text {. }\end{array}$ \\
\hline delayed litigation & $=$ & $\begin{array}{l}\text { Indicator variable }=1 \text { if AAER or shareholder litigation event occurs after } 12 \text { months but } \\
\text { before five years of Wells notice disclosure, otherwise } 0 .\end{array}$ \\
\hline earnchg & $=$ & $\begin{array}{l}e p s p x_{t-1}-e p s p x_{\mathrm{t}-2} \text { (for annual earnings announcements) or } e p s p x q_{q t-1}-e p s p x q_{q t-5} \text { (for } \\
\text { quarterly earnings announcements) scaled by } c s h o \text { at end of year } t-1 \text { or quarter } q t-1 \text {. }\end{array}$ \\
\hline earnchg_ind & $=$ & Indicator variable $=1$ if earnchg greater than median in year $t$, otherwise 0 . \\
\hline $\begin{array}{l}\text { earnings } \\
\text { announcement }\end{array}$ & $=$ & $\begin{array}{l}\text { Indicator variable }=1 \text { for Wells disclosure days with earnings announcements on days }-2 \\
\text { to } 2 \text {, otherwise } 0 .\end{array}$ \\
\hline ex-ante litigation risk & $=$ & $\begin{array}{l}\text { Litigation risk estimated using the coefficients from Eq. (2) of Kim and Skinner (2012, } \\
\text { p. 302). }\end{array}$ \\
\hline growth & $=$ & $\begin{array}{l}\text { Book value of shareholders' equity (ceq) divided by market capitalization ( } \operatorname{csho} x \\
\operatorname{prcc}_{-} f \text { ), at end of year } t-1 \text {. }\end{array}$ \\
\hline $\begin{array}{l}\text { high ex-ante litigation } \\
\text { risk }\end{array}$ & $=$ & $\begin{array}{l}\text { Indicator variable }=1 \text {, if } e x \text {-ante litigation risk from Eq. (2) of Kim and Skinner (2012, p. } \\
302) \text { is greater than sample median, otherwise } 0 .\end{array}$ \\
\hline$i m r$ & $=$ & $\begin{array}{l}\text { Inverse Mills ratio from first-stage regression model of a firm's decision to disclose a } \\
\text { Wells notice. }\end{array}$ \\
\hline industry & $=$ & $\begin{array}{l}\text { Indicator variable }=1 \text { if the firm is in the biotech (SIC codes } 2833-2836 \text { and } 8731-8734) \text {, } \\
\text { computer }(3570-3577 \text { and } 7370-7374) \text {, electronics (3600-3674), or retail (5200-5961) } \\
\text { industries, otherwise } 0 .\end{array}$ \\
\hline investment & $=$ & Capital expenditure (capx) divided by total assets (at), at end of year $t-1$. \\
\hline leverage & $=$ & Long-term debt ( $d l t t)$ divided by total assets $(a t)$, at end of year $t-1$. \\
\hline $\log c \operatorname{shrs}$ & $=$ & 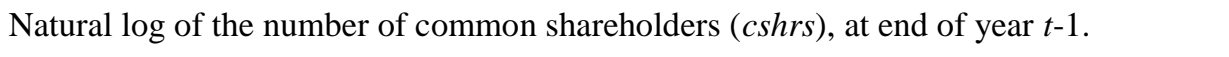 \\
\hline $\log$ mktcap & $=$ & Natural log of market capitalization, at end of year $t-1$. \\
\hline $\log$ tradvol & $=$ & Natural log of the annual trading volume, for year $t-1$. \\
\hline loss & $=$ & Indicator variable $=1$ if the firm reports a loss at end of year $t-1$, otherwise 0 . \\
\hline ibes & $=$ & Number of analysts following stock, at end of year $t-1$. \\
\hline ibes stdev & $=$ & Standard deviation of ibes EPS consensus forecast, at end of year t-1. \\
\hline prior litigation & $=$ & $\begin{array}{l}\text { Indicator variable }=1 \text { if AAER or shareholder litigation event in prior five years of a } \\
\text { Wells notice disclosure, otherwise } 0 .\end{array}$ \\
\hline profitability & $=$ & Income before extraordinary items $(i b)$ for year $t-1$ divided by $a t$, at end of $t-1$. \\
\hline retvolat & $=$ & $\begin{array}{l}\text { Standard deviation of monthly stock return over } 60 \text { months ending the month before the } \\
\text { Wells notice disclosure date. }\end{array}$ \\
\hline roavolat & $=$ & Standard deviation of return on assets over past five years, to $t-1$. \\
\hline size & $=$ & Natural logarithm of total assets (at), at end of year $t-1$. \\
\hline subsequent litigation & $=$ & $\begin{array}{l}\text { Indicator variable }=1 \text { if AAER or shareholder litigation event occurs within five years of } \\
\text { a Wells notice disclosure, otherwise } 0 .\end{array}$ \\
\hline timely litigation & $=$ & $\begin{array}{l}\text { Indicator variable }=1 \text { if AAER or shareholder litigation event occurs within } 12 \text { months } \\
\text { of a Wells notice disclosure, otherwise } 0 .\end{array}$ \\
\hline tradvol & $=$ & Annual trading volume for year $t-1$. \\
\hline xret & $=$ & $\begin{array}{l}\text { Return on stock for day } t \text { minus the return on the value-weighted index of stocks in the } \\
\text { CRSP database, where } t \text { is relative to the day of a Wells notice disclosure. }\end{array}$ \\
\hline
\end{tabular}

* The italicized terms in the second column refer to Compustat definitions of these variables. 
Appendix B. Example of first-time and subsequent Wells disclosure

Progress Software Corporation

First release: 8-K filed on February 11, 2009 (abstract)

On February 5, 2009, Progress Software Corporation (the "Company") received a "Wells Notice" from the Securities and Exchange Commission ("SEC") in connection with the previously disclosed ongoing SEC investigation into the Company's historical stock option granting practices. The Company believes that the matters covered by the Wells Notice were the subject of a previously disclosed internal investigation into the Company's stock option granting practices conducted by a Special Committee of the Board of Directors of the Company. The Company has been advised that its Vice President, Corporate Controller and Chief Accounting Officer has also received a Wells Notice in connection with the same matter.

Second release: 10-Q filed on April 9, 2009 for the Quarterly Period Ended February 28, 2009

Note 12: Contingencies (abstract)

On February 5, 2009, we received a "Wells Notice" from the SEC in connection with the SEC investigation into our option-granting practices. We have been advised that our Vice President, Corporate Controller has also received a Wells Notice in connection with the same matter. The Wells Notices notify recipients that the SEC staff intends to recommend that the SEC file a civil action against the recipients for possible violations of securities laws. Under the process established by the SEC, recipients have the opportunity to respond in writing to a Wells Notice before the SEC staff makes any formal recommendation regarding what action, if any, should be brought by the SEC. We have provided a written submission to the SEC as part of the Wells Notice process. In connection with the contemplated recommendation, the SEC staff may seek remedies, including among other things, a permanent injunction, a civil penalty and, in the case of individuals, a bar against serving as a director or officer of a public company. There can be no assurance that the SEC will not bring civil enforcement action against any recipient of a Wells Notice. As previously disclosed, we have been cooperating with the SEC since we first publicly disclosed these matters in 2006 , and we continue to do so.

Third release: $10-K$ filed on June 1, 2009 (abstract)

On June 1, 2009, Progress Software Corporation (the "Company") received written notice from the Staff of the Division of Enforcement (the "Staff") of the United States Securities and Exchange Commission (the "SEC") that the SEC's investigation of the Company's historical stock option granting practices has been completed and that the Staff does not intend to recommend any enforcement action against the Company. The Company has also been informed that the Staff has completed its investigation and will not recommend any enforcement action against the individual who serves as the Company's Vice President, Corporate Controller and Chief Accounting Officer relating to the same matter.

\section{Notes}

Note 1. The term "Wells notice" arose from recommendation no. 16 of the advisory committee report on SEC enforcement policies and practices (SEC, 1972), chaired by John Wells, that states as follows: "Except where the nature of the case precludes, a prospective defendant or respondent should be notified of the substance of the staff's charges and probable recommendations in advance of the submission of the staff memorandum to the Commission recommending the commencement of an enforcement action and be accorded an opportunity to submit a written statement to the staff which would be forwarded to the Commission together with the staff memorandum." (p. iv). For additional background on SEC enforcement policies and practices, see Atkins and Bondi (2008) and Winer and Winer (2011).

Note 2. Not all Wells disclosures need have market consequences for other reasons also, for instance, in the case of a misinterpretation of the facts, which the firm would make clear to the SEC through a Wells submission (see, also, sub-section 0)

Note 3. Early disclosure of a Wells notice may also provide new clues for research firms (e.g., Disclosure Insight, Inc.) that specialize in analyzing investigations reported in SEC filings. Some firms use the Freedom of Information Act to acquire, otherwise, nonpublic information. We comment further on the relation between timely disclosure and subsequent litigation in sub-section 0 .

Note 4. Receipt of a Wells notice is not only a signal of a possible AAER action, shareholder litigation event, or 
restatement. Through later events, a Wells notice could also trigger manager dismissal, a debt covenant violation, and analyst downgrading (Karpoff, Lee, \& Martin, 2008b; Burks, 2010).

Note 5. A review of "significant empirical research" conducted in recent years on the enforcement of the federal securities laws also finds no studies that control for the market response to a Wells notice (Bai, Cox, \& Thomas, 2010).

Note 6. Appendix B provides an example.

Note 7. The variables and time subscripts are described in Appendix A.

Note 8. The variables and time subscripts are described in Appendix A.

Note 9. Of all the models in Table 7, Eq. (2) has the highest pseudo- $\mathrm{R}^{2}$. We also developed coefficient estimates based on the Wells sample, but those coefficients were not significant due to small sample size, and so we did not use them for predictive purposes. We also considered other models of litigation risk (e.g., Jones \& Weingram, 1996, Skinner, 1997) but use Kim and Skinner (2012) as the most up-to-date analysis in this area.

Note 10. For discussions and applications of the Heckman approach in the accounting and finance literatures, see Lennox, Francis, and Wang, 2012; Tucker 2010; and Larcker and Rusticus 2010. The Heckman approach is a commonly used technique to evaluate firms' self-disclosure decisions. Also, Files, Swanson, and Tse (2009) examine whether disclosure prominence associates with the negative stock reaction around the disclosure of accounting restatements. Because of self-selection, they adopt the Heckman approach to first predict managers' choice to disclose prominently or not. They then include the inverse Mills ratio in the second stage model to predict stock price reaction.

Note 11. We choose this approach because Eq. (2) is a disclosure model for firms with litigation risk generally and not an overall model of litigation risk, and, therefore, it should reflect both disclosure and litigation risk attributes. However, as with all models of this kind, while conceptually grounded, their empirical nature also makes them partly ad hoc. We comment further on the disclosure model in Section 0 on results.

Note 12. Early bad news disclosure could also mitigate the cost of disclosing otherwise later proprietary information (Suijs, 2005).

Note 13. As an additional test, we also analyze Wells disclosures with a subsequent AAER action versus those with subsequent shareholder litigation and an AAER action by repeating the above analyses. Untabulated results show similar mean excess stock return for both groups.

Note 14. We also attempted to address the selection issue by making a FOIA (Freedom of Information Act) request to the SEC. We requested a listing of all Wells letters, the dates of issuance, and the firm names and their CIK between 2000 and 2012. The SEC responded with a list of names and dates of Wells Notice recipients that became subject to an SEC action and the name of the action to which the recipient was named from the beginning of its "electronic tracking" in 2011 to December 31, 2012. We then performed an analysis by comparing Wells disclosers with all Wells recipients to establish if disclosers differ significantly from non-disclosers in firm characteristics, which could confound the interpretation of our analyses. As with the main study, we defined Wells disclosers as firms that disclosed the Wells receipt in a $10-\mathrm{K}, 10-\mathrm{Q}$, or $8-\mathrm{K}$, and non-disclosers as firms that were listed in the SEC's FOIA response but chose not to disclose in an SEC filing. This FOIA file contained 644 Wells notices from 2011 to December 2012. We first obtained the GVKEY firm identifier from Compustat by matching on firm names. Since most of the Wells receipt names or Wells action names denote individuals rather than firms, we found that only 47 out of 644 Wells observations had a GVKEY. Within these 47 Wells notices, we found multiple notices for the same firm in the same year. We assigned such multiple observations as a single case. This gave us 31 firm-year Wells observations. Among these 31 observations, only 11 firm-years had financial variables such as assets, book value of equity, or earnings available between 2011 and 2012. Of the 31 cases, four firms disclosed Wells receipt in an SEC filing and the remaining 27 were non-disclosers. Given the limited number of Wells disclosers and non-disclosers, we decided not to perform a statistical comparison between disclosers and non-disclosers.

Note 15. Untabulated results show that the mean bid-ask spreads for Wells disclosure days -1 and 0 generally exceed the mean spreads for days $-3,-4$, and -5 for all panels of Table 6 . 